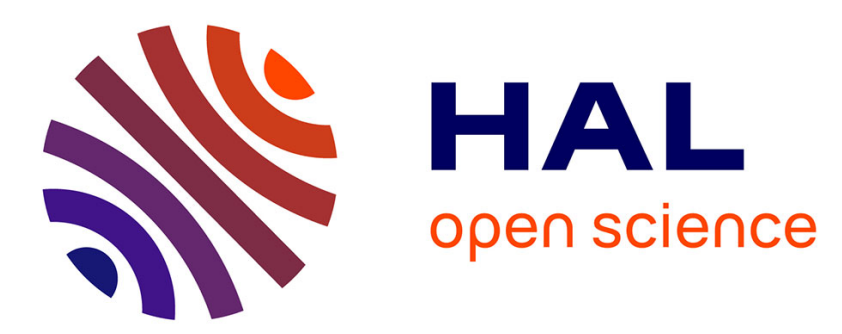

\title{
Vive la Différence: Social Banks and Reciprocity in the Credit Market
}

Simon Cornée, Ariane Szafarz

\section{To cite this version:}

Simon Cornée, Ariane Szafarz. Vive la Différence: Social Banks and Reciprocity in the Credit Market. Journal of Business Ethics, 2013, 125 (3), pp.361-380. 10.1007/s10551-013-1922-9 . halshs-00874615

\section{HAL Id: halshs-00874615 https://shs.hal.science/halshs-00874615}

Submitted on 18 Oct 2013

HAL is a multi-disciplinary open access archive for the deposit and dissemination of scientific research documents, whether they are published or not. The documents may come from teaching and research institutions in France or abroad, or from public or private research centers.
L'archive ouverte pluridisciplinaire HAL, est destinée au dépôt et à la diffusion de documents scientifiques de niveau recherche, publiés ou non, émanant des établissements d'enseignement et de recherche français ou étrangers, des laboratoires publics ou privés. 


\title{
Vive la Différence: \\ Social Banks and Reciprocity in the Credit Market
}

\author{
Simon Cornée \\ Université de Rennes 1, CREM UMR CNRS 6211, and CERMi \\ Faculté des Sciences Economiques \\ 7, place Hoche CS 86514 \\ 35065 Rennes cedex \\ FRANCE \\ simon.cornee@univ-rennes1.fr
}

Ariane Szafarz

Université Libre de Bruxelles (ULB), SBS-EM, CEB, and CERMi

50, av. F.D. Roosevelt, CP114/03

1050 Brussels

BELGIUM

aszafarz@ulb.ac.be

September 2013

Keywords: Social bank; reciprocity; social identity.

JEL Codes: G21, D63, G24, H25

\footnotetext{
*The authors thank Yiorgos Alexopoulos, Francesca Barigozzi, Régis Blazy, Carlo Borzaga, Damien Brousolle, Isabelle Cadoret, Anastasia Cozarenco, Jacques Defourny, Joeffrey Drouard, Silvio Goglio, Marek Hudon, Marc Jegers, Panu Kalmi, Georg Kirchsteiger, Philipp Koziol, Marc Labie, Neil McHugh, Fabien Moizeau, Jonathan Morduch, Tomasso Oliveiro, Anaïs Périlleux, Jose Luis Retolaza, Michael Roberts, Leire San-Jose, Jessica Schicks, Hubert Tchakoute Tchuigoua, Piero Tedeschi, Gregory Udell, Olaf Weber, Laurent Weill, the participants at the CERMi Seminar, ULB (May 2012), the "Cooperative Finance and Sustainable Development" Conference at the University of Trento (June 2012), the "Frontiers of Finance" Workshop at the Paris Panthéon Sorbonne University (October 2012), the Workshop on SME Finance at the University of Strasbourg (April 2013), the Third European Research Conference on Microfinance at the University of Agder (June 2013), the "Finance and Society" Workshop at BEM/KEDGE Business School (June 2013), the EMES Conference in Liège (July 2013), as well as an anonymous referee for helpful comments and discussions. This research has been carried out in the framework of an "Interuniversity Attraction Pole" on social enterprise, funded by the Belgian Science Policy Office.

- Corresponding author
} 


\begin{abstract}
Social banks are financial intermediaries paying attention to non-economic (i.e. social, ethical, and environmental) criteria. To investigate the behavior of social banks on the credit market, this paper proposes both theory and empirics. Our theoretical model rationalizes the idea that reciprocity can generate better repayment performances. Based on a unique handcollected dataset released by a French social bank, our empirical results are twofold. First, we show that the bank charges below-market interest rates for social projects. Second, regardless of their creditworthiness, motivated borrowers respond to advantageous credit terms by significantly lowering their probability of default. We interpret this outcome as the first evidence of reciprocity in the credit market.
\end{abstract}

Keywords: Social bank; reciprocity; social identity.

JEL Codes: G21, D63, G24, H25 


\section{Introduction}

Reciprocity in the credit market is a phenomenon whereby borrowers who consider themselves fairly treated by the credit institution need no enforcement devices (incentives, monitoring, etc.) to repay their debt swiftly. Reciprocity is typically based on trust and common values. It can act as a powerful antagonist to perverse mechanisms such as moral hazard and strategic default, which are known to plague the functioning of credit markets (Jaffee and Rusel, 1976; Stiglitz and Weiss, 1981; Brown et al., 2009). However, the feasibility for a bank to inspire reciprocity in its borrowers seems to be a challenge, if not an illusion. Doubts about this feasibility are especially relevant in the current context where the credit crisis has deeply compromised the reputation of the financial sector.

Still, there is good news. Experimental evidence supports the existence of reciprocity in the credit market (Fehr and Zehnder, 2006; Brown and Zehnder, 2007; Cornée et al., 2012). Moreover, Karlan (2005) observes that laboratory evidence is often consistent with real-life behavior in financial matters. So far, however, no study has ever confirmed the existence of reciprocity in real-life credit markets. This paper fills the gap by using a database released by a French social bank. To this end, we investigate the bank's behavior in loan granting and the resulting repayment conduct of the borrowers. We show that moral values shared by the bank and its motivated borrowers lead to a two-step virtuous mechanism. In the first place, the social bank proposes advantageous credit terms to its motivated borrowers. Then, these borrowers respond by defaulting less frequently than their standard counterparts. We also propose a simple model to rationalize the facts.

The role of other-regarding preferences in economic decision making has attracted increasing attention from scholars over the last twenty years. While there is considerable heterogeneity in agents' attitudes, evidence demonstrates that not everyone maximizes self- 
interest. In particular, a substantial fraction of the population exhibits social preferences. Fehr and Schmidt (2003) show that a share of $40 \%$ to $60 \%$ of the population pursues fairness by favoring pro-social outcomes even if this implies forgoing personal gains. Similarly, Fehr and Fischbacher (2002) find that a number of people are willing to sacrifice material payoffs to reward kind actions or punish unfriendly ones. Socially-minded agents tend to share windfall gains in equitable ways even though they stand no chance of benefiting from doing so. They also tend to sanction people who split gains unfairly. People with social preferences still care for their self-interest, but in addition they exhibit a concern for fairness (Fehr and Schmidt, 1999) and/or reciprocity (Rabin, 1993; Dufwenberg and Kirchsteiger, 2004; Adbulkardiroglu and Bagwell, 2013). Experimental evidence indicates that reciprocity is a powerful motivation for contract enforceability. This is especially the case when the contract is incomplete and the agent's commitment is unobservable (Fehr et al., 1997; Gächter and Falk, 2004; Brown et al., 2009).

More generally, social identity seems to be a driving force for reciprocity. Social identity is generally defined as an individual's sense of self, derived from perceived membership of a relevant social group (Chen and Li, 2009). Each individual has several social identities stemming among other things from gender, ethnicity, nationality, social class, and corporate culture. These more or less salient identities affect attitudes. And they can have major implications for economic decisions and outcomes. In the model proposed by Akerlof and Kranton (2000), identities are associated with behavioral prescriptions or norms. Individuals who deviate from these prescriptions suffer disutility. Interestingly, identities may play a crucial role in the case of principal-agent setting with contract incompleteness and unobservable effort, such as the lender-borrower relationship. Social identification, i.e. the fact that the agent identifies herself with her principal's values, can mitigate moral hazard problems. Akerlof and Kranton (2005) argue that such a phenomenon occurs in employment 
relationships. In addition, social identification fosters reciprocity (Chen and Li, 2009; McLeish and Oxoby, 2011). Agents reciprocate more intensively if they identify with counterparty to a trade than if they do not.

In the credit market, borrowers' reciprocity may thus stem from their social identification with the lender. In this regard, social banks offer fertile ground for investigation. By nature, social-or ethical-banks pay attention to the non-economic (i.e. social and environmental) consequences of their activity (Green, 1989; Taupin and Glémain, 2007; Benedikter, 2011; Weber and Remer, 2011). These banks pass the financial sacrifices of their motivated shareholders and savers through to borrowing firms, which share the social values the banks wish to promote. They thus act, at least partly, as drivers of corporate social responsibility (Scholtens, 2006) or "philanthropic intermediaries" (Benabou and Tirole, 2010). Their main goal consists in serving community-oriented projects and social enterprises, which put the emphasis not only on financial returns but also-and often chieflyon social aims (Defourny, 2001). Even though social banks are still niche institutions, they have spread considerably in recent years. Between 2007 and 2010, their asset growth rate reached $53.41 \%$, compared with $8.37 \%$ for mainstream banking. ${ }^{1}$ In Europe, their stronghold, their combined assets exceeded $€ 20$ billion in $2009{ }^{2}$

Notwithstanding their increasingly popularity and the fact that they represent an alternative to conventional banking, evidence on social banks' operating methods is scant. Here we offer two major contributions. First, we set up a simple theoretical model in which the interest rate charged by the social bank acts as a credible signal of value-sharing by the social bank and a motivated borrower. In this model the borrower's project choice is not enforceable by the bank. However, the social bank is ready to invest in a costly screening

\footnotetext{
${ }^{1}$ Own calculations based on the figures in GABV (2012).

${ }^{2}$ We refer to the figures of the European Federation of Ethical and Alternative Banks (FEBEA) available on www.febea.org.
} 
device that allows it to recognize the motivated borrowers, i.e. the ones who share its social values. Accordingly, the bank signals their privileged status to these borrowers by offering them a low interest rate. Then, in line with their social identity, rationalized by a positive cost of cheating, the motivated borrowers reciprocate the bank's gesture by undertaking an efficient investment project with a low default risk.

Second, we conduct an empirical analysis. We exploit a unique hand-collected dataset including detailed information on 389 business loans granted by a French social bank between 2001 and 2004. Each borrower in our sample is graded on both a social and a financial scale. The social bank uses the social rating to measure the degree of proximity between its own social identity and that of borrowers. The bank is thus able to identify its motivated borrowers. In line with the theoretical model, our empirical results show that the bank charges lower interest rates to its motivated borrowers, all else being equal. We also find that these borrowers repay more swiftly than others with equal ex ante creditworthiness. We complete the study by carrying out a rough cost-benefit analysis of reciprocity. It appears that the benefits of reciprocity do not offset the costs associated with both the interest rate rebate and social screening.

The rest of this paper is organized as follows. Section 2 presents our model on social banking and reciprocity. Section 3 introduces our database. Sections 4 and 5 investigate the interest rate charged by the bank, and the probability of default, respectively. Section 6 proposes a cost-benefit analysis of reciprocity. Section 7 offers robustness checks. Section 8 concludes. 


\section{A Model of Social Banking and Reciprocity}

The recent financial crisis has revealed the limits of mainstream banking and put alternative forms of financial intermediation into the spotlight. In particular, social banks characterized by a double bottom line have become increasingly popular. Somewhat surprisingly, they remain poorly investigated in the academic literature. Accordingly, this section starts with a short overview of the sector. Next, it presents a simple model explaining how reciprocity can emerge in social banking.

Beyond their economic function, social banks aim to foster a community of values by matching the two sides of financial intermediation: socially-minded investors (i.e. shareholders and savers) and motivated borrowers. Social banks are financial intermediaries with a double bottom line. ${ }^{3}$ They advertise social achievements as their main goal. Financial concerns are justified by the need for economic sustainability rather than profit maximization (Becchetti and Garcia, 2011; Becchetti et al., 2011; San-Jose et al., 2011). In addition, social banks are ruled by foundational principles such as transparency, accountability, and fair redistribution of profits (Cowton and Thompson, 2000; Cowton, 2002; Bechetti et al., 2011; San-Jose et al., 2011). ${ }^{4}$

Regarding investment strategy, social banks follow two fundamental rules. First, they commit themselves to finance the "real economy." They grant credit to projects with social value added. Second, they ban purely speculative transactions (San-Jose et al., 2011). Their financial transactions rely on simple intermediation, and result in high deposits-to-assets and

\footnotetext{
${ }^{3}$ We henceforth use "social bank" to describe any bank claiming to pay attention to extra-financial criteria, regardless of their specific nature, be they social, ethical, or environmental. Arguably, a triple bottom line may be advocated (Global Report Initiative, 2011) insofar as social banks often combine ethical and environmental concerns. Akin to other works on socially responsible lending (e.g. Gutierrez-Nieto et al., 2011; Allet and Hudon, 2013), we consider environmental concern as part of social concerns. Moreover, Norman and MacDonald (2004) state that the triple-bottom-line rhetoric may be misleading and act as a smokescreen.

${ }^{4}$ Becchetti et al. (2011) identify the following foundational principles of social banks: 1) awareness of noneconomic consequences, 2) access to finance as a human right, 3) efficiency and probity, 4) fair redistribution of profits, 5) full transparency, 6) encouragement of active involvement of shareholders and savers in decision making, and 7) ethical inspiration in all activities.
} 
loans-to-assets ratios. Social banks also differentiate themselves from their commercial counterparts by adopting specific corporate governance rules. They favor the involvement of stakeholders in strategic and operational decision making (San-Jose et al., 2011). To prevent the presence of dominant shareholders, most social banks operate under the legal status of cooperatives $(\mathrm{GABV}, 2012) .^{5}$ The few that have a capitalistic ownership structure rely on self-regulatory arrangements to limit power concentration. For example, shareholders' voting rights at Alternative Bank Schweiz (ABS, Switzerland) and Triodos Bank (The Netherlands and Belgium) are capped. ${ }^{6}$ Alternative forms of stakeholder involvement are promoted, such as the participation of non-shareholders in governing and executive bodies.

How do social banks put their social mission into practice? The stakeholders' identitysharing $^{7}$ with the bank is essential to capture social banks' operating methods. In line with Akerlof and Kranton's (2000) theory, socially-minded investors put their money into a social bank in order to receive an extra stream of utility and reinforce their pro-social identity. Subsequently, they are ready to forgo a significant part of their financial returns as long as the social bank funds motivated borrowers, i.e. borrowers aiming at financing a pro-social business project. The intensity of the investors' social motivation can be measured by their financial sacrifice, in other words the spread between the interest paid to them by a social bank and by a comparable mainstream bank. Becchetti and Garcia (2011) evaluate this sacrifice at Banca Etica, an Italian social bank, at around 150 basis points in 2007. The bank's

\footnotetext{
${ }^{5}$ Cooperative status affects not only the design of the institution's governance but also the capital structure of its balance sheet. Iannotta et al. (2007) and Ferri et al. (2010) show that financial cooperatives tend to be better capitalized than commercial retail banks. Plausibly, this set-up is stronger in social banks. Management can use the diffuse ownership structure to easily retain earnings within the bank (Périlleux et al., 2012). This strategy is in line with the investors' commitment to forgo financial returns in exchange for the accomplishment of the bank's social mission. In addition, the cooperative status helps aligning the managers' behavior with the bank's social mission (Kitson, 1996). Becchetti and Huybrechts (2008) draw the same conclusion for fair-trade organizations.

${ }^{6}$ Each ABS shareholder must remain below the three-percent voting-right threshold. Triodos Bank's shares are held in trust by an ad hoc foundation, whose board is appointed by depository receipt holders with limited voting rights.

${ }^{7}$ We only consider the two key categories of stakeholders: investors (shareholders, savers) and borrowers, and disregard other categories such as the staff. Nevertheless, Cornée et al. (2012) show that employees of social banks exhibit higher social preferences than their counterparts working in mainstream banks.
} 
owners also make sacrifices. San-Jose et al. (2011, p. 152) report that "ethical banks do not generally distribute benefits between shareholders and, if at all they do so, the distribution is very limited, and profit is, therefore, only residual."

Capturing the way social banks operate in the credit market is far more complex for at least two reasons. First, as demonstrated by Stiglitz and Weiss (1981), in imperfect markets with asymmetric information, interest rates will not perform their clearing function. The credit market is thus characterized by credit rationing, and the demand side of the market is partially unobservable. Second, credit scoring is bank-specific, even for small-business lending alone (Cowan and Cowan, 2006). For social banks, the issue is even more acute due to the presence of a double bottom line. In addition, the interaction of social and financial missions remains poorly elucidated, and stylized facts on credit terms are scarce. In the context of microcredit, ${ }^{8}$ Hudon (2007) emphasizes that the level of interest rates is instrumental from an ethical standpoint. In our model, the interest rate is the device used by a social bank to signal identity-sharing with motivated borrowers.

Credit allocation is only one side of the problem. To obtain a global picture of how social banks' system of reciprocity operates, we also need to pay attention to the way borrowers behave. Typically, asymmetric information prevents the lender from observing the borrowers' actual investment choice. We thus need an alternative rationale for motivated borrowers behaving virtuously toward the social bank. In the model proposed by Bariggozzi and Tedeschi (2011), a motivated borrower who trades with the social bank perceives an extra stream of utility if her project is successful. Therefore, a forward-looking motivated borrower is more willing to repay her debt to a social bank than to a profit-maximizing one. In this

\footnotetext{
${ }^{8}$ Paradoxically, more evidence is available on microfinance institutions active in developing countries than on social banks active in developed countries. The existing evidence on microcredit activity is, however, not transposable to social banking because the microcredit lending methodology is specific. It is based on the supply of standardized small loans without collateral (Armendariz and Morduch, 2010). Microfinance institutions typically charge identical interest rates to most - if not all - borrowers, and simply tailor loan size to their borrowers' perceived creditworthiness (Agier and Szafarz, 2013a).
} 
framework, the borrower's reaction is dictated by the nature of the social bank, not by a signal. In the real world, however, borrowers constitute a heterogeneous set of agents. They need a credible signal to realize that they belong to the bank's privileged clientele. Once a borrower has learned about her privileged status, she might wish to reciprocate the gesture by making an efficient investment with a low default risk. In our model, this mechanism is rationalized by introducing the cost of cheating, which is incurred by motivated borrowers only.

Let us now present our model. Consider a social bank active in a competitive credit market with two types of borrowers: opportunistic and motivated. A social bank differs from a mainstream bank in the way it screens loan applicants. Its goal is to target motivated borrowers and offer them fair credit terms. To do so, the social bank pays the extra costs associated with its social screening mechanism. In practice, screening is based on an evaluation of the applicants' motivation. As a result, the social bank is able to recognize motivated borrowers. These borrowers share an identity with the social bank, and this makes them reluctant to cheat on their project choice. Parameter $c$ denotes the (positive) cost of cheating for motivated borrowers. ${ }^{9}$ In contrast, opportunistic borrowers face zero cost of cheating. We assume that the social bank not only observes the type of each borrower but also correctly estimates parameter $c$.

In line with Fehr and Zehnder (2006), we assume that all the borrowers are risk-neutral and have the choice between two projects. First, project $A$ is an efficient low-risk project yielding return $\bar{R}_{A}$ with probability $\pi_{A}$ and zero return with probability $\left(1-\pi_{A}\right)$. Second, project $B$ is an inefficient high-risk project yielding return $\bar{R}_{B}\left(>\bar{R}_{A}\right)$ with probability continuum of motivated borrowers characterized by their degree of motivation, defined by their cost of cheating. 
$\pi_{B}\left(<\pi_{A}\right)$ and zero return with probability $\left(1-\pi_{B}\right)$. Borrowers have limited liability: The repayment of a loan cannot exceed the return on the project.

All the loans have the same size, normalized to one. Each borrower applies for the financing of a given project $(A$ or $B)$, but asymmetric information makes it impossible for the bank to enforce the undertaking of the announced project. The social bank is a price-taker. The market interest rates are $r_{A}$ on project $A$ and $r_{B}$ on project $B$, with $r_{B}>r_{A}$. We assume that:

$\pi_{B}\left(\bar{R}_{B}-\left(1+r_{A}\right)\right) \geq \pi_{A}\left(\bar{R}_{A}-\left(1+r_{A}\right)\right) \geq \pi_{B}\left(\bar{R}_{B}-\left(1+r_{B}\right)\right)$

which implies that ex ante the borrowers are better off applying for project $A$ and undertaking it than applying for project $B$ and undertaking it. Therefore, no borrower will ever apply for a loan by announcing project $B$. However, once the loan is released, the choice of project is private information to the borrower and cannot be enforced by the bank. As a result, opportunistic borrowers will apply for credit with project $A$ but will subsequently undertake project $B$. Since the social bank observes the type of each borrower, it will charge rate $r_{B}$ to opportunistic borrowers.

In contrast, motivated borrowers face a trade-off: Either they announce project $A$ and subsequently undertake project $A$, or they announce project $A$ but then cheat and undertake project $B$. In the first case, their expected profit is $\pi_{A}\left(\bar{R}_{A}-(1+r)\right)$, where $r$ is the interest rate charged by the bank. In the second, the expected profit is $\pi_{B}\left(\bar{R}_{B}-(1+r)\right)-c$. More precisely, a motivated borrower will undertake project $A$ if:

$\pi_{A}\left(\bar{R}_{A}-(1+r)\right)>\pi_{B}\left(\bar{R}_{B}-(1+r)\right)-c$ or equivalently if: 
$\pi_{B} \bar{R}_{B}-\pi_{A} \bar{R}_{A}<c-\left(\pi_{A}-\pi_{B}\right)(1+r)$

Hence, the project choice of the motivated borrowers depends on the interplay between the interest rates, $r_{A}$ and $r_{B}$, and the cost of cheating, $c$. According to Eq. (2), we have three possibilities:

(i) $\quad c$ is high: $\pi_{B} \bar{R}_{B}-\pi_{A} \bar{R}_{A}<c-\left(\pi_{A}-\pi_{B}\right)\left(1+r_{A}\right)<c-\left(\pi_{A}-\pi_{B}\right)\left(1+r_{B}\right)$

(ii) $\quad c$ is moderate: $c-\left(\pi_{A}-\pi_{B}\right)\left(1+r_{A}\right)<\pi_{B} \bar{R}_{B}-\pi_{A} \bar{R}_{A}<c-\left(\pi_{A}-\pi_{B}\right)\left(1+r_{B}\right)$

(iii) c is low: $c-\left(\pi_{A}-\pi_{B}\right)\left(1+r_{A}\right)<c-\left(\pi_{A}-\pi_{B}\right)\left(1+r_{B}\right)<\pi_{B} \bar{R}_{B}-\pi_{A} \bar{R}_{A}$

In the two polar cases, (i) and (iii), the behavior of the motivated borrowers does not depend on the interest rate charged. In case (i), cheating is very costly and the borrowers will undertake project $A$. Since the bank estimates the value of $c$ correctly, it knows that the announcement of project $A$ is trustworthy. Therefore, it will charge rate $r_{A}$. In case (iii), the cost of cheating is low enough to make the borrowers cheat regardless of the interest rate charged by the bank. Accordingly, the informed bank will charge rate $r_{B}$. Motivated borrowers facing a low cost of cheating behave like their opportunistic counterparts.

The situation depicted in case (ii) is more interesting. The decision of motivated borrowers facing moderate cheating costs depends on the rate charged by the bank. If the bank charges rate $r_{A}$, the borrower will not cheat and undertake project $A$. Alternatively, if the bank charges rate $r_{B}$, cheating becomes more profitable than being trustworthy, and the borrowers will undertake project $B$. Remarkably, in case (ii) the social bank determines the borrowers' project choice even though the bank can neither observe nor enforce it.

To further interpret the findings of the model, let us compare the situations of standard and social banks. A standard bank shares no identity with its borrowers. Hence, it charges all of them $r_{B}$, and ends up financing inefficient high-risk projects only. In contrast, by sharing 
an identity with some of its borrowers, namely the motivated ones, the social bank manages to finance efficient low-risk projects. It does so by charging rate $r_{A}$ to borrowers facing moderate or high cheating costs. Actually, these borrowers know that they are privileged by the bank because they are charged $r_{A}$ rather than $r_{B}$. In the real life, borrowers perceive this credible signal when negotiating the credit terms.

In practice however, identifying motivated borrowers and estimating their individual cost of cheating can prove very costly for the social bank. This may explain why social banks are ultimately less profitable than standard ones. In the framework of our empirical study, we interpret the social rating (SR) as an estimate of the cost of cheating. This follows from the intuition that for a borrower, higher motivation entails a higher cost of cheating a social bank. Moreover, the model shows that among the motivated borrowers, those with a high value of $c$ will never cheat while others, with a moderate value of $c$, will refrain from cheating only if the bank signals its confidence by charging rate $r_{A}$. In this case, the signal will generate reciprocity in the form of undertaking project $A$.

Overall, the message from our model is that social banks serving, at least partly, motivated borrowers end up with a less risky loan portfolio than do standard banks, and thus obtain better repayment performances. They also enhance global welfare by increasing the share of efficient low-risk projects in the economy. Nevertheless, given the additional screening costs faced by social banks, the overall differences in profitability between standard and social banks remain ambiguous. We will further explore this issue in Section 5. 


\section{Data and Preliminary Analysis}

The hand-collected data used in this study come from $\mathrm{La} \mathrm{Nef,}{ }^{10}$ a French social bank established in 1988. San-Jose et al. (2011) list La Nef among the social banks that best align their managerial deeds with their ethical principles. La Nef is a financial cooperative operating throughout France under the supervision of Banque de France, the French central bank. With 27,135 members in 2010 , it had total assets amounting to $€ 288$ million. La Nef implements basic intermediation rules. Its resources come from the savings ${ }^{11}$ of cooperative members, who are motivated by social returns. This motivation is testified by financial returns lying slightly above inflation (La Nef's annual report, 2010), which is consistent with the financial sacrifice of 150 basis-points mentioned by Becchetti and Garcia (2011) for Banca Etica. La Nef is committed to transparency, publishing details of its investments every year. This constitutes a channel for direct relationships between savers and borrowers.

Our study stretches from 2001 to 2008 . We consider loans granted over the 2001-2004 period. In addition, we use a four-year window (2005-2008) to record the occurrences of default. ${ }^{12}$ During the 2001-2004 period, La Nef operated three branches, ${ }^{13}$ and its clientele was spread all over France (see Table A1 in Appendix A). ${ }^{14}$ Loans are extended to borrowers in rural areas $(50.41 \%)$, town and cities $(25.07 \%)$, and suburbs $(24.52 \%)$. This geographic dispersion is linked to the diversity of activities funded by La Nef. The pool of borrowers is mainly composed of small businesses, community-oriented project holders, and social enterprises. Over the 2001-2004 period, the bank granted 630 loans. Only 476 of them were

\footnotetext{
${ }^{10}$ See www.lanef.com.

${ }^{11}$ In 2010 , its deposits-to-assets ratio was $85.92 \%$ and its loans-to-assets ratio was $40.12 \%$, which is quite low. However, the resources not directly used for loans are entrusted to Le Crédit Coopératif, a partner cooperative bank sharing La Nef's social values. In 2010, this represented 35.76\% of the balance sheet (La Nef, 2010).

${ }^{12}$ The data were collected in November 2008. The sample period for loan granting stretches from January 1 , 2001 to November 25, 2004. The November 2004-November 2008 period is used only as a feedback period.

${ }^{13}$ Since September 2007, La Nef has operated four branches.

14 The Ile-de-France, Provence-Alpes-Côtes-d'Azur and Rhône-Alpes regions are overrepresented since they include the three largest French cities: Paris, Marseille and Lyon, respectively.
} 
effectively extended. We managed to gain access to the complete credit files for 389 extended loans, which gives our sample 81 percent representativeness. Missing files are proportionately less frequent in the second half of the sample period (see Table 1), due to improvements in the bank's information system. $^{15}$

Table 1: Sample Yearly Composition

\begin{tabular}{|c|c|c|c|}
\hline Year & Extended loans & Observed loans & Representativeness \\
\hline $\mathbf{2 0 0 1}$ & 87 & 50 & $57.47 \%$ \\
\hline $\mathbf{2 0 0 2}$ & 106 & 84 & $79.25 \%$ \\
\hline $\mathbf{2 0 0 3}$ & 143 & 129 & $90.21 \%$ \\
\hline $\mathbf{2 0 0 4}$ & 140 & 126 & $90.00 \%$ \\
\hline Full sample & $\mathbf{4 7 6}$ & $\mathbf{3 8 9}$ & $\mathbf{8 1 . 7 2 \%}$ \\
\hline
\end{tabular}

The borrowers are relatively young businesses (5.34 years old, on average) and include $49 \%$ of start-ups. Average turnover is about $€ 540,000$, and the average number of employees is 7.59. These companies operate in four sectors: environmental protection and ecology (46\%), fair trade and community-based services (30\%), culture and health (12\%), economic inclusion and microfinance (12\%). Regarding legal status, $43.5 \%$ are unlimited companies, $37.5 \%$ are limited companies, and $19 \%$ are cooperatives. ${ }^{16}$ All the loans are pledged with collateral. The average level of collateralization is equal to $84 \%$, in line with the figures for mainstream banking (see Becchetti and Garcia, 2011). This, however, contrasts with the $42 \%$ of uncollateralized loans reported by Becchetti and Garcia (2011) for Banca Etica. The difference is likely attributable to the fact that Banca Etica trades with borrowers belonging to consortiums. Hence, existing long-term relationships between these consortiums and the bank

\footnotetext{
${ }^{15}$ Most likely, our sample does not suffer from a selection bias. The missing loans were excluded by accident, not on purpose. Unfortunately, we had no access to information on the denied applications. This in turn limits the possibility of observing the bank's full selection process.

${ }^{16}$ Due to data unavailability, some statistics have been obtained from reduced samples. Location and loan officers are known for 367 firms, age and firm status for 369, and turnover and staff for 55.
} 
act as a substitute for collateral, even though the consortiums themselves provide no formal guarantee for the loans.

Table 2 presents the variables used in the empirical study, broken down into four categories. First, each borrower is characterized by a financial rating (FIN) and a social responsibility rating (SR). These ratings are established in-house by the loan officers who systematically pay a visit to the applicants.

Both ratings are given on a one-to-three scale, three being the best grade. The FIN rating gives a general appraisal on both backward-looking and forward-looking perspectives. It assesses 1) business risks and prospects, 2) financial statements, and 3) profitability. Since the bank's clientele includes a large share of start-ups, this approach is more relevant to its practice than the conventional backward-looking point-in-time measure used to evaluate bankruptcy risks (Grunert et al., 2005).

The SR rating assesses the foreseen social and environmental accomplishments of the project. This rating is assigned in two steps. The credit officer who meets up with the credit applicant on the spot makes the first appraisal. Then, the credit committee makes the final decision according to guidelines provided by the so-called ethics committee appointed by the board of the bank. In contrast to FIN, SR is not determined according to strict rules. Rather, it involves judgments on non-tangible characteristics, such as moral rectitude, social motivation, the ethicality and environment-friendliness of the business activity, and corporate responsibility towards stakeholders. These characteristics can be interpreted as an assessment tool for the proximity between the applicant's and the bank's social identities. La Nef's Annual report (2006) sets out the assessment guidelines. "SR $=1$ " means that granting the loan would favor financial inclusion, i.e. no special characteristics are necessary for the applicant; "SR $=2 "$ means the applicant is concerned with environmental or social 
responsibility; "SR = 3" means the applicant is concerned with environmental and social responsibility.

Second, the three contractual features of the loans are: charged interest rate (RATE), loan size in $€ 10,000$ (LOANSIZE), and share of the loan that is not collateralized (NONCOLLAT). These features are set by the bank.

Third, as in previous studies (Petersen and Rajan, 1994; Berger and Udell, 1995; Elsas and Krahnen, 1998), for each loan we have collected the same-day three-month Paris Inter Bank Offered Rate (PIBOR3M), which proxies the bank's refinancing rate.

Table 2: Variables in the Database

\begin{tabular}{|c|c|}
\hline VARIABLES & DEFINITIONS \\
\hline \multicolumn{2}{|r|}{ Financial and social ratings } \\
\hline FIN & Financial rating: from 3 (excellent) to 1 (distress) \\
\hline SR & Social responsibility rating: from 3 (best) to 1 (worst) \\
\hline \multicolumn{2}{|r|}{ Contractual features } \\
\hline RATE & Nominal rate at which the loan is granted (100 basis points) \\
\hline LOANSIZE & Amount extended in $€ 10,000$ \\
\hline NONCOLLAT & Share of the loan unpledged by collateral (in \%) \\
\hline \multicolumn{2}{|r|}{ Refinancing interest rate } \\
\hline PIBOR3M & Three-month Paris Inter Bank Offered Rate (100 basis points) \\
\hline \multicolumn{2}{|r|}{ Additional characteristics } \\
\hline STARTUP & $=1$ if the loan is extended to a start-up; 0 otherwise \\
\hline RELATIONSHIP & $\begin{array}{l}=1 \text { if the firm had a banking relationship prior to loan approval; } 0 \\
\text { otherwise }\end{array}$ \\
\hline DEFAULT & $\begin{array}{l}=1 \text { if the firm defaults within the four years after loan extension; } 0 \\
\text { otherwise }\end{array}$ \\
\hline
\end{tabular}


Fourth, three dummy variables account for the borrowing firm being a start-up (STARTUP), having a banking relationship prior to loan extension (RELATIONSHIP), and having experienced a default within the four years following loan extension, respectively. The first two characteristics are observed by the bank when determining credit condition; the third is observed ex post.

Table 3: Descriptive Statistics by Social Responsibility Levels

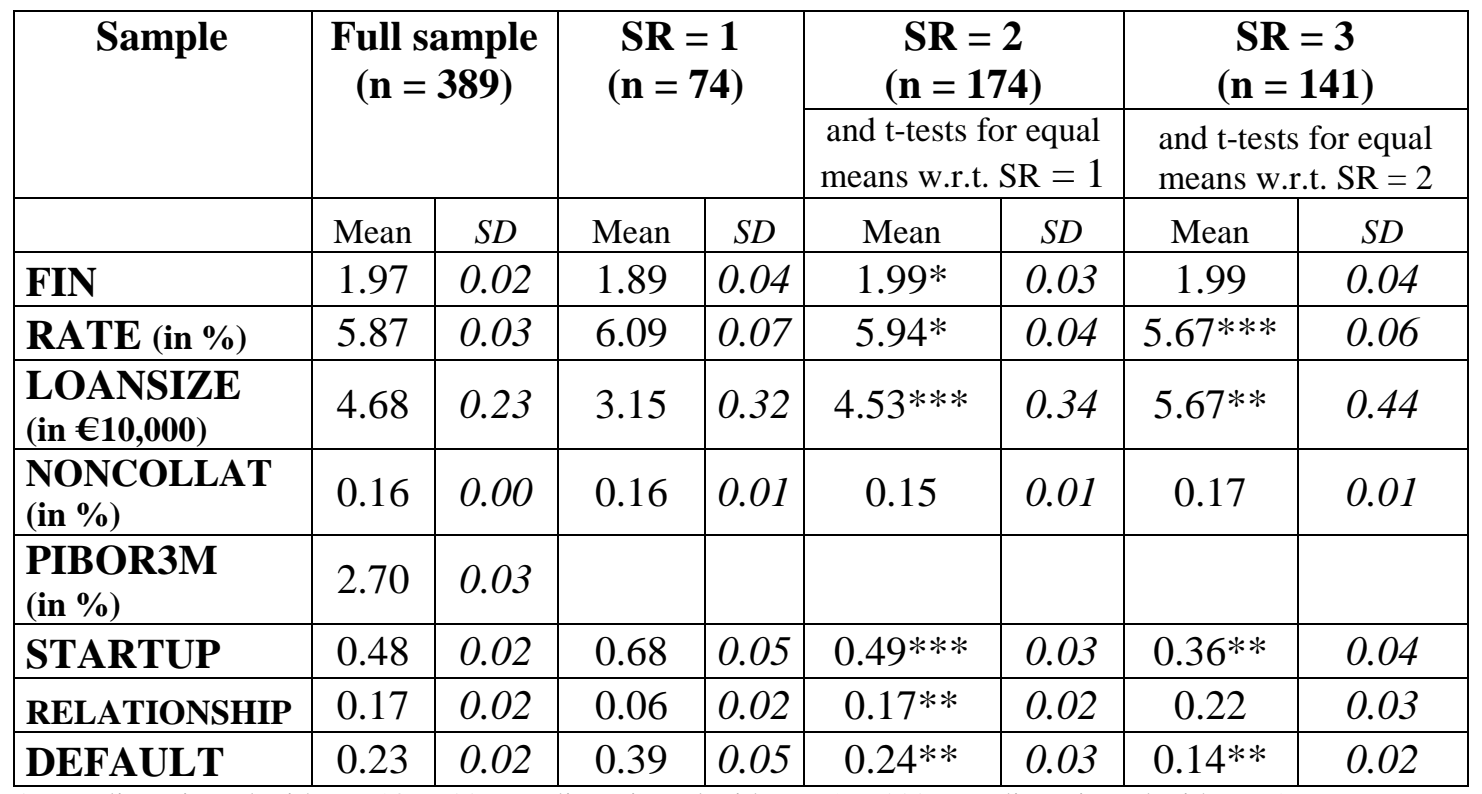

*: equality rejected with $\mathrm{p}<10 \%, * *$ : equality rejected with $\mathrm{p}<5 \%$, ***: equality rejected with $\mathrm{p}<1 \%$

Table 3 gives an overview of the whole sample as well as figures averaged within fixed SR levels, and tests for differences across these levels. It appears that $18 \%$ of the funded projects have a low $\mathrm{SR}$ rating $(\mathrm{SR}=1), 44 \%$ have a mid-range one $(\mathrm{SR}=2)$, and $38 \%$ have a high one ( $\mathrm{SR}=3$ ). In line with its mission, the bank favors socially oriented projects, but its portfolio is not restricted to high-SR projects. This may be attributable to diversification motives and/or scarcity of such projects. ${ }^{17}$

The yearly interest rate charged by the bank is $5.87 \%$ on average, while the average refinancing rate (PIBOR3M) is $2.70 \%$ over the period. The average loan size is $€ 46,800$. In

\footnotetext{
${ }^{17}$ The relatively low loans-to-assets ratio $(40.12 \%)$ may derive from a scarcity of social projects that break even.
} 
line with the bank's social mission, the interest rate charged is negatively related to SR, while loan size is positively related to it. Collateralization, in contrast, is insensitive to SR, since the non-collateralized share of the loans varies little (between 15\% and 17\%). Most importantly, the social and financial ratings seem weakly related.

Table 3 indicates that the share of start-ups decreases with SR. Startups represent $83 \%$ of the firms with $\mathrm{SR}=1$, but only $57 \%$ of those with $\mathrm{SR}=2$, and $40 \%$ of those with $\mathrm{SR}=3$. One possible explanation lies in the bank's prudence in assessing SR for start-ups. Information asymmetries are evidently high for start-ups. This evidence points to the necessity of taking the start-up status explicitly into account in the regression analysis. In the same vein, benefitting from a relationship with the bank increases the likelihood of reaching higher SR, but this effect is significant only for the transition from $\mathrm{SR}=1$ to $\mathrm{SR}=2$.

A full $23 \%$ of the borrowing firms experienced repayment issues within the four-year period following loan extension. These issues, grouped under the "default" denomination, are: moratoriums, loan provisions, credit withdrawals, disposal of collateral, and liquidation. This broad definition of default is consistent with the recommendation issued by the Basel Committee on Banking Supervision (Second Consultative Document, 2001, recommendation 272). Based on out-of-sample figures from 2007, we estimate that around $15 \%$ of the defaulted loans are eventually liquidated. According to this estimate, only $3.5 \%$ of the bank's loan portfolio would end up in liquidation. Expectedly, defaults are more frequent for startups (32\%) than for existing firms (14\%). Based on 2007 data, we estimate that liquidation concerns about $2 \%$ of the loans extended to existing companies and about $5 \%$ to start-ups. Default occurrences decrease sharply with SR. Passing from SR $=1$ to $\mathrm{SR}=3$ lowers the 
probability of default from 0.39 to $0.14 .^{18}$ This key figure will be further explored in Section 5.

On the whole, the descriptive statistics reveal that high-SR firms get lower interest rates and higher loan sizes, which is consistent with the bank's stated social orientation. At this stage, however, we cannot exclude that credit conditions are also determined by other factors interacting with SR.

Table 4: Correlation Matrix: All Firms

\begin{tabular}{|l|c|c|c|c|l|l|l|}
\hline & SR & FIN & RATE & LOANSIZE & $\begin{array}{l}\text { NON } \\
\text { COLLAT }\end{array}$ & STARTUP & $\begin{array}{l}\text { RELATIO } \\
\text { NSHIP }\end{array}$ \\
\hline SR & 1.00 & & & & & & \\
\hline FIN & 0.05 & 1.00 & & & & & \\
\hline RATE & $-0.27 * * *$ & $-0.12 * *$ & 1.00 & & & & \\
\hline LOANSIZE & $0.19 * * *$ & 0.05 & $-0.25^{* * * \mathrm{p}}$ & 1.00 & & & \\
\hline NONCOLLAT & -0.00 & $-0.08^{*}$ & $-0.18^{* * * \mathrm{P}}$ & $0.07^{\mathrm{p}}$ & 1.00 & & \\
\hline STARTUP & $-0.22 * * *$ & -0.05 & 0.06 & $-0.24 *$ & $0.15^{* * *}$ & 1.0000 & \\
\hline $\begin{array}{l}\text { RELATIONSH } \\
\text { IP }\end{array}$ & $0.13 * * *$ & $0.17 * * *$ & $-0.14 * * *$ & 0.02 & -0.00 & $-0.36 * * *$ & 1.0000 \\
\hline DEFAULT & $-0.20 * * *$ & $-0.14 * * *$ & 0.04 & -0.02 & 0.07 & $0.21 * * *$ & $-0.15 * * *$ \\
\hline
\end{tabular}

Subscript " $p$ " means Pearson correlations, the other correlations are Spearman rank correlations.

$*$ : zero correlation rejected with $\mathrm{p}<10 \%$, **: zero correlation rejected with $\mathrm{p}<5 \%$, ***: zero correlation rejected with $\mathrm{p}<1 \%$

Social banks can support motivated borrowers in at least two ways. First, they can help social firms otherwise redlined by profit-oriented credit providers. Second, they can provide below-market credit conditions, such as low interest rates, to profitable projects in order to increase the chances of success. While these two strategies may be combined, their practical consequences are dramatically different. In the first case, the social bank acts as a substitute for public subsidy, and launches social but unprofitable activities. In the second, it acts as a profit accelerator for already well-performing social firms, a target mostly disregarded by public funding schemes. To empirically disentangle these strategies, we use the correlation between the financial and social ratings of the selected projects.

\footnotetext{
${ }^{18}$ Loan-loss provisioning is governed by law. Therefore, we rule out the possibility that loans with different social ratings are treated differently by the bank.
} 
Table 4 gives the correlation matrix. The most important figure concerns the correlation between the social and financial ratings. Because our sample is made up of granted loans only, it is subject to an endogenous selection bias. Assuming that the pool of applicants is large enough to let the bank make a meaningful selection, we view the correlation between the two ratings as a consequence of the selection mechanism. Accordingly, a negative correlation in our sample would signal that the selection is less stringent for motivated borrowers than for standard ones. In contrast, a positive correlation would be incompatible with the bank's social mission. ${ }^{19}$

Table 4 reveals that the correlation between the two ratings is not significantly different from zero. We interpret this key figure as the consequence of a selection mechanism that is not biased towards high SR ratings. In particular, this is consistent with the bank using a financial-based denial rule, such as rejecting below-break-even projects. This type of rule is frequent in mainstream banking. In social banking, it is often combined with a similar rule rejecting projects with below-standard social ratings. What matters from our standpoint is that the social rating is not used to mitigate the importance of the financial rating in the selection phase. As a consequence, we rule out the possibility that the bank is softer on social projects. The social bank does not target social projects with low profitability. Rather, it seems concerned with enhancing the probability of success of viable social projects. By concentrating on profitable projects, the social bank acts as a complement to public funding schemes rather than a substitute for them.

Table 4 also indicates that the interest rate exhibits significantly negative correlations with both ratings, social and financial. Low interest rates tend to be associated with large

\footnotetext{
${ }^{19}$ Admittedly, this argument would be stronger if we had access to data on denied loans, which is unfortunately not the case. Instead, we rely here on the assumption that the loan selection is made within a pool of applications large enough to allow the bank to make unconstrained choices. Although this assumption is debatable, we see no realistic scenario that would make the observed zero correlation spurious.
} 
loans, high collateralization, and existing banking relationship. The latter finding is consistent with empirical studies suggesting that the cost of credit decreases as a function of the intensity of the banking relationship (Berger and Udell, 1995; Uzzi, 1999; Berger et al., 2007).

Start-ups tend to face lower collateral requirements. This striking correlation may be explained by the fact that, in France, loans to start-ups are often secured by public guarantee funds. In all, $69.02 \%$ of start-up loans are guaranteed by public collateral $(41.68 \%$ of total loans). ${ }^{20}$ Public collateral is highly reliable because it is automatically released when loans are liquidated. As a result, the bank needs proportionately less public than private collateralization to reach a given level of guarantee.

The zero correlation between RELATIONSHIP and NONCOLLAT in Table 4 is counter-intuitive. A large body of empirical studies strongly supports the argument that relationship lending reduces collateral requirements (Petersen and Rajan, 1994; Berger and Udell, 1995; Boot, 2000; Degryse and Van Cayseele, 2000; Chakraborty and Hu, 2006). In our sample, though, the raw correlation may be flawed by ignoring the STARTUP factor, which is correlated positively with NONCOLLAT and negatively with RELATIONSHIP. The regression analysis will confirm that the apparent anomaly disappears when the start-up status is properly accounted for.

Unlike previous studies (Petersen and Rajan, 1994; Berger and Udell, 1995; Elsas and Krahnen, 1998), we use the charged interest rate (RATE) and the refinancing rate (PIBOR3M) as two distinct variables (see Table 2), instead of focusing solely on their difference-the spread. This choice is motivated by the joint movements of the variables at stake. Fig. 1 draws the dynamics of three variables: RATE, PIBOR3M, and the spread. From 2001 to 2004, RATE steadily decreased, roughly following PIBOR3M. Over the same period,

\footnotetext{
${ }^{20}$ These percentages are obtained from a sub-sample of 367 firms.
} 
the spread experienced a dramatic shift, widening from $2.40 \%$ in 2001 to $3.39 \%$ in $2003 .^{21}$ This shift may result from the use of a rate-smoothing strategy. In periods of downtrending market interest rates, banks tend to charge higher spreads in order to rebuild their margins (Machauer and Weber, 1998). Conservatively, we have decided to work with both the RATE and PIBOR3M variables, the former being a dependent variable, the latter an independent one. The resulting econometric specifications are more flexible than those built from the spread only. ${ }^{22}$

\section{Figure 1: Charged Interest Rate, Refinancing Rate (PIBOR3M), and Spread}

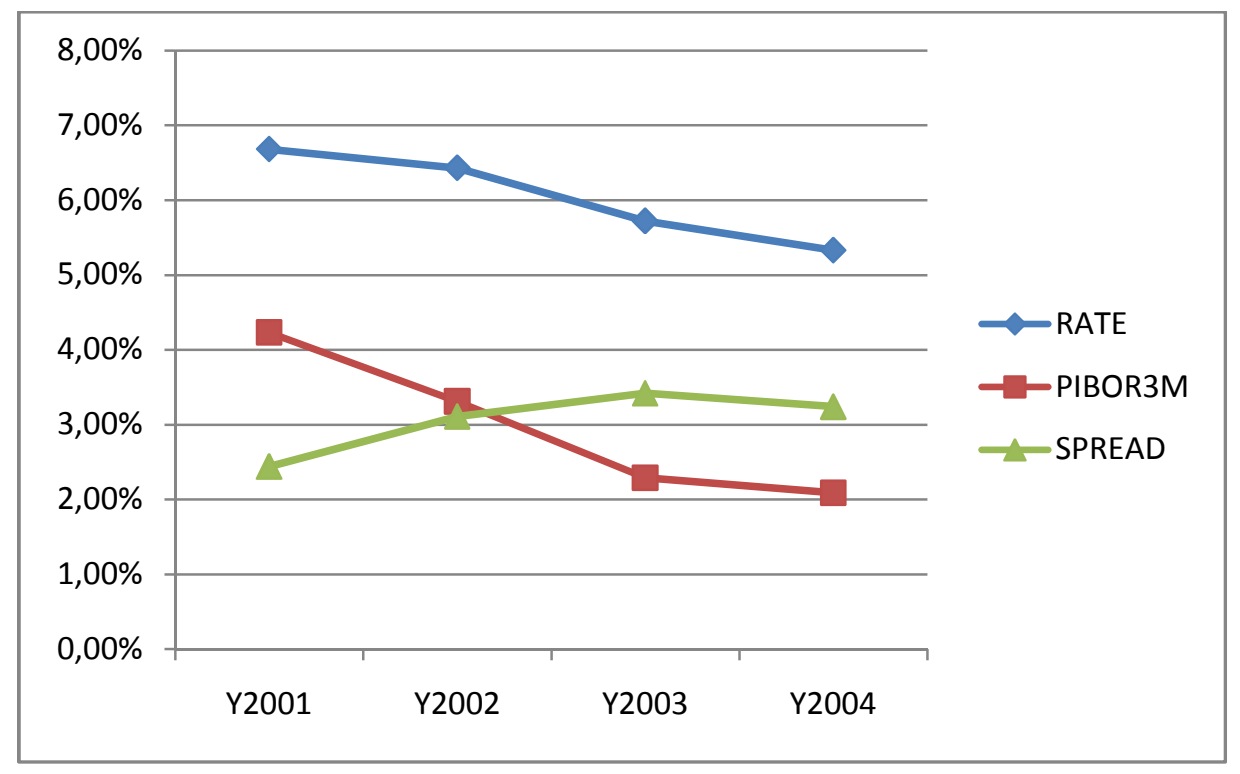

\section{Impact of Social Rating on Interest Rate}

In this section, we examine how the social rating influences the interest rate that the social bank charges its borrowers. The social rating is our focus because this is what makes social banks special among credit providers. In the empirical literature, little is known about the way

\footnotetext{
${ }^{21}$ The overall evolutions of the FIN and SR variables are stable. This excludes the possibility for the shift in spreads being driven by a change in the composition of the clientele.

${ }^{22}$ We have also estimated a model explaining the spread. The estimation results are similar to those in Table 5 (Section 4), regarding signs, amplitudes, and levels of significance. However, explaining the spread rather than the interest rate is detrimental to the quality of fit.
} 
social characteristics affect the interest rates charged by social banks. We investigate this issue through regression analysis.

Table 5 presents the results for four specifications explaining the interest rate. In specification (1), the main explanatory variables are the social (SR) and financial (FIN) ratings. The benchmark interest rate (PIBOR3M) is added to account for the bank's refinancing rate. This specification makes sense if one assumes that all the borrowers' characteristics are well summarized by the two ratings. Specification (2) takes explicitly into consideration the two variables related to informational asymmetries, namely STARTUP and RELATIONSHIP. These variables are included because the borrowers know more about the characteristics of their own projects than the lender does. Specification (3) adds loan size and collateralization. These two variables interact with the interest rate, as shown by the correlation matrix in Table 4. However, including them as explanatory variables might raise an endogeneity issue because the three credit conditions (interest rate, loan size, and collateralization) are simultaneously determined. To address this issue, we also estimate a multivariate model for the three credit terms (see Table $\mathrm{C} 1$ in Appendix $\mathrm{C}$ ). The estimates obtained from the multivariate regression are similar to those from the univariate regressions for the interest rate.

In specification (4), year dummies account for incomplete-and subsequently excludedfiles, which are proportionately more frequent during the first year of observation. Besides, the global economic climate might also have influenced both the bank's lending strategy and the creditworthiness of its borrowers. Allowing for year effects is a way to correct for biases potentially introduced by these two facts. Specification (4) also controls for loan officers, who play a crucial role in SR measurement. However, complete information on loan officers is available for only a sub-sample of 367 firms. Therefore, specification (4) is estimated on a reduced sample. 
Table 5: Interest Rate: OLS Estimations

\begin{tabular}{|c|c|c|c|c|}
\hline VARIABLES & $\begin{array}{c}(1) \\
\text { RATE }\end{array}$ & $\begin{array}{c}(2) \\
\text { RATE }\end{array}$ & $\begin{array}{c}(3) \\
\text { RATE }\end{array}$ & $\begin{array}{c}(4) \\
\text { RATE }\end{array}$ \\
\hline SR & $\begin{array}{c}-0.16^{* * *} \\
(0.031)\end{array}$ & $\begin{array}{c}-0.15 * * * \\
(0.032)\end{array}$ & $\begin{array}{c}-0.13 * * * \\
(0.032)\end{array}$ & $\begin{array}{l}-0.08 * * \\
(0.032)\end{array}$ \\
\hline FIN & $\begin{array}{c}-0.16^{* * *} \\
(0.047)\end{array}$ & $\begin{array}{c}-0.15^{* * *} \\
(0.048)\end{array}$ & $\begin{array}{c}-0.16^{* * * *} \\
(0.047)\end{array}$ & $\begin{array}{c}-0.15^{* * *} \\
(0.046)\end{array}$ \\
\hline PIBOR3M & $\begin{array}{c}0.61 * * * \\
(0.029)\end{array}$ & $\begin{array}{c}0.61 * * * \\
(0.029)\end{array}$ & $\begin{array}{c}0.59 * * * \\
(0.030)\end{array}$ & $\begin{array}{c}0.42^{* * *} \\
(0.091)\end{array}$ \\
\hline STARTUP & & $\begin{array}{c}0.03 \\
(0.050)\end{array}$ & $\begin{array}{c}-0.01 \\
(0.050)\end{array}$ & $\begin{array}{c}-0.02 \\
(0.049)\end{array}$ \\
\hline RELATIONSHIP & & $\begin{array}{c}-0.02 \\
(0.066)\end{array}$ & $\begin{array}{c}-0.02 \\
(0.065)\end{array}$ & $\begin{array}{c}-0.04 \\
(0.063)\end{array}$ \\
\hline LOANSIZE & & & $\begin{array}{c}-0.02 * * * \\
(0.005)\end{array}$ & $\begin{array}{c}-0.02 * * * \\
(0.005)\end{array}$ \\
\hline NONCOLLAT & & & $\begin{array}{c}-0.15 \\
(0.146)\end{array}$ & $\begin{array}{c}-0.15 \\
(0.145)\end{array}$ \\
\hline CONSTANT & $\begin{array}{c}4.86^{* * * *} \\
(0.140)\end{array}$ & $\begin{array}{c}4.84 * * * \\
(0.148)\end{array}$ & $\begin{array}{l}4.99 * * * \\
(0.152)\end{array}$ & $\begin{array}{l}5.39 * * * \\
(0.407)\end{array}$ \\
\hline Year dummies & No & No & No & Yes \\
\hline Loan officer dummies & No & No & No & Yes \\
\hline Observations & 389 & 389 & 389 & 367 \\
\hline R-squared & 0.57 & 0.57 & 0.59 & 0.61 \\
\hline
\end{tabular}

Table 5 shows that, in all specifications, both the social and the financial ratings influence the charged interest rate negatively. Specification (2) shows that STARTUP and RELATIONSHIP have no direct impact on the determination of the interest rate. The Rsquared obtained for Specification (3) is hardly affected by the inclusion of loan size and collateralization. Still, the load of loan size is significantly negative. This could indicate that social banks favor larger loans.

As expected, higher financial ratings are valued in terms of lower interest rates. More interestingly, social firms get cheaper credit from the bank, all other things being equal. The bank's social orientation results in interest rate rebates to social firms. This rebate is interpreted as a social premium. More precisely, a one-unit increase in the social rating is 
associated with an eight to sixteen basis-point premium in the charged interest rate. ${ }^{23}$ Qualitatively speaking, this result confirms the findings of the theoretical model that the social bank charges a lower interest rate to borrowers exhibiting higher motivation.

\section{Social Rating and Probability of Default}

In this section, we study the reactions of motivated borrowers who benefit from a social premium. To check whether the social premium influences repayment performance, we use the information on defaults. A loan is said to be defaulted if the borrower experiences reimbursement issues during the four years after the loan was granted. ${ }^{24}$

In Table 6, we estimate the probability of default through probit estimations ${ }^{25}$ under several specifications, for the sake of robustness. In specification (1), only the social and financial ratings are used to explain default probability. Specification (2) controls for the two variables associated with asymmetric information. Specification (3) also includes the credit conditions. Last, specification (4) takes into account year and loan-officer dummies.

Table 6 reports the marginal effects at the mean. There is overwhelming evidence of significantly negative impacts of both the social and the financial ratings on default probability. Interestingly, these two effects share similar sizes in all specifications. This is confirmed by formal tests for equal coefficients. While the negative impact of the financial rating on default probability was expected, that of the social rating was not, especially since both ratings are uncorrelated. Moreover, both effects are far from negligible. An additional unit of any rating brings around a $10 \%$ decrease in the probability of default.

\footnotetext{
${ }^{23}$ The loading of SR in specification (4) is lower than in the previous specifications. Presumably, this is because, unlike FIN ratings, the SR ratings are determined somewhat subjectively by loan officers.

${ }^{24}$ The loans are extended for periods varying from one to twenty years. This four-year convention, fixed by the bank, is thus somewhat arbitrary. Still, $87 \%$ of defaults occur within the four years following credit granting.

${ }^{25}$ Logit estimations (not reported) bring similar results.
} 
Table 6: Probability of Default: Probit Estimations

\begin{tabular}{|c|c|c|c|c|}
\hline & (1) & (2) & (3) & (4) \\
\hline VARIABLES & DEFAULT & DEFAULT & DEFAULT & DEFAULT \\
\hline \multirow[t]{2}{*}{ SR } & $-0.11 * * *$ & $-0.09 * * *$ & $-0.09 * * *$ & $-0.10 * * *$ \\
\hline & $(0.029)$ & $(0.029)$ & $(0.029)$ & $(0.030)$ \\
\hline \multirow[t]{2}{*}{ FIN } & $-0.13 * * *$ & $-0.12 * * *$ & $-0.12 * * *$ & $-0.11 * *$ \\
\hline & $(0.046)$ & $(0.046)$ & $(0.046)$ & $(0.047)$ \\
\hline \multirow[t]{2}{*}{ STARTUP } & & $0.12 * * *$ & $0.13 * * *$ & $0.11 * *$ \\
\hline & & $(0.045)$ & $(0.045)$ & $(0.047)$ \\
\hline \multirow[t]{2}{*}{ RELATIONSHIP } & & -0.09 & -0.10 & $-0.10 *$ \\
\hline & & $(0.056)$ & $(0.056)$ & $(0.055)$ \\
\hline \multirow[t]{2}{*}{ RATE } & & & -0.02 & -0.01 \\
\hline & & & $(0.034)$ & $(0.051)$ \\
\hline \multirow[t]{2}{*}{ LOANSIZE } & & & 0.00 & 0.00 \\
\hline & & & $(0.005)$ & $(0.005)$ \\
\hline \multirow[t]{2}{*}{ NONCOLLAT } & & & -0.01 & 0.06 \\
\hline & & & $(0.154)$ & $(0.162)$ \\
\hline Year dummies & No & No & No & Yes \\
\hline Loan officer dummies & No & No & No & Yes \\
\hline Observations & 389 & 389 & 389 & 367 \\
\hline $\log (\mathrm{L})$ & -199.22 & -191.60 & -191.15 & -180.64 \\
\hline
\end{tabular}

There are two possible explanations for the impact of the social rating on default probability. First, higher ratings encourage significant rebates in interest rates. This automatically decreases the borrower's financial burden and makes the loans easier to reimburse. This "rational" explanation is, however, contradicted by the estimation of specification (3), which controls for credit conditions in general, and interest rates in particular. None of the credit conditions has a significant direct influence on the probability of default. In addition, the financial benefits associated with interest rate rebates are modest given the historically low levels of rates over the study period.

The second, more convincing explanation involves a reciprocity effect driven by favorable credit conditions acting as a signal. This is the gist of our theoretical model. The results in Table 6 demonstrate that motivated borrowers virtuously respond to fair credit 
conditions by increasing the effort they put into meeting their financial obligations to the social lender. Accordingly, our estimations provide the first empirical confirmation of the intuition that reciprocity exists in credit markets, posited by Fehr and Zehnder (2004) and Brown and Zehnder (2007) and formalized in our model.

Still, we cannot rule out that at least some motivated borrowers exhibit a lower probability of default regardless of the interest rate rebate they receive. In our theoretical model, the borrowers with a high cost of cheating do not need a signal to undertake an efficient low-risk project. However, even in that situation the social bank supplies them with the fair interest rate corresponding to the risk level of their actual project. Similarly, one could imagine that some of $\mathrm{La} \mathrm{Nef's} \mathrm{motivated} \mathrm{borrowers} \mathrm{would} \mathrm{spontaneously} \mathrm{make} \mathrm{a} \mathrm{greater}$ effort to fulfill their project than would their same-creditworthiness opportunistic counterparts. This could simply be due to the fact that they are dealing with a social bank. If this is the case, the interest rate rebate is a "pure gift" from the bank, stemming from a shared social identity. Empirically, "pure gift" and reciprocity are impossible to disentangle because they appear to be observationally equivalent.

It could even be that motivated borrowers are more concerned with fulfilling their projects than are other borrowers regardless of the financing institution. They would then exhibit good repayment performances in relation to any bank, social or not. One could object to the argument that if socially-responsible borrowers were systematically more trustworthy than opportunistic ones, then banks would have learned this from experience. As a result, assessing social responsibility would have become part and parcel of standard financial assessment. In practice, this is obviously not the case. Conversely, it is generally very difficult to obtain financial support from mainstream banks for social projects. This fact is actually the very reason for the emergence of social banks. 


\section{Cost-Benefit Analysis of Reciprocity}

To gauge the economic impact of reciprocity for a social bank, we sketch a cost-benefit evaluation of La Nef's socially-oriented lending policy. The net benefit of reciprocity in year $t, N B R_{t}$, is the difference between the benefit of reciprocity and its costs. The benefit stems from the decrease in default occurrences. The costs are twofold. First, motivated borrowers receive social premiums, which result in lower interest cashed in by the bank. Second, the social bank faces specific costs associated with social screening. $N B R_{t}$ is thus computed in the following way:

$N B R_{t}=\Delta C D_{t}-\Delta I_{t}-S C_{t}$

where $\Delta C D_{t}$ is the year- $t$ reduction in the cost of default driven by the virtuous repayment conduct of motivated borrowers, $\Delta I_{t}$ is the year- $t$ reduction in cashed-in interests stemming from social premiums offered to motivated borrowers, and $S C_{t}$ represents the year- $t$ screening costs associated with assessing the applicants' social ratings.

Evaluating the components of $N B R_{t}$ is an arduous task entailing the possibility of significant measurement errors. Here, we outline the basic assumptions, while providing technical details in Appendix B. When discounting is needed, we use a 6\% rate corresponding to a rough estimate of the bank's weighted average cost of capital. ${ }^{26}$

First, to estimate $\Delta C D_{t}$ we use the bank's loan-loss provisions (LLPs), which reflect the expectations of future losses on defaulted loans. ${ }^{27}$ To derive the share of LLPs attributable to the bank's social orientation, we need a benchmark. Hence, we introduce a hypothetical nonsocial bank serving the same clientele as La Nef. This benchmark bank is assumed to grant

\footnotetext{
${ }^{26}$ Sensitivity analysis reveals that variations in this parameter have little effect on the estimates of the $N B R_{t}$ 's.

${ }^{27}$ Loans in default are non-performing loans at least 90 days in arrears. Actually, LLP can also be manipulated strategically. For instance, banks have incentives to use provisions to manage earnings and regulatory capital as well as to signal information about future prospects (Ahmed et al., 1999). Nevertheless, working with differential—rather than absolute—costs likely offsets any strategic biases.
} 
credit in the same way that La Nef treats its clients, with $\mathrm{SR}=1$. Doing so neutralizes the effects of reciprocity embedded in granting advantageous conditions to borrowers with $\mathrm{SR}=$ 2 and $\mathrm{SR}=3$. We use regression analysis to simulate the cash flows generated by the benchmark bank, and proxy $\triangle C D_{t}$ by taking the differences between these simulated cash flows and the ones observed for La Nef.

Second, to compute $\Delta I_{t}$, we rely on the results from Table 5 (specification (3)). ${ }^{28} \mathrm{We}$ determine the loan-specific rebates on interest rates with respect to the $\mathrm{SR}=1$ benchmark. For each loan with $\mathrm{SR}=2$ and 3, we simulate the yearly interest payments forgone by the social bank over the duration of the loan and we add up their discounted values. Summing all the forgone payments in year $t$ yields our estimation of $\Delta I_{t}$.

Third, the cost of social screening, $S C_{t}$, is hardest to assess. The burden associated with social screening translates into higher costs for at least two reasons: the bank's timeconsuming screening technique and the geographic dispersion of the borrowers. Financially sustainable social projects are scarce. The bank is thus inclined to search for business opportunities all over the country. In addition, the borrower's evaluation is systemically conducted on-site by a loan officer. Ultimately, $50.41 \%$ of the loans are extended to borrowers living in remote rural areas. To get a sense of the excess operating costs attributable to the search for and assessment of social projects, we compare the $80 \%$ operating ratio of La Nef to that of comparable French banks over the same period. ${ }^{29}$ We use data from La Nef's annual reports and estimate $S C_{t}$ as the share of overhead expenses for screening operations dedicated to the social screening in year $t$.

\footnotetext{
${ }^{28}$ We use specification (3) rather than specification (4) in order to carry out the analysis on the full sample.

${ }^{29}$ For French banks, Gouteroux (2006) and Ory et al. (2006) obtain operating ratios of between $62.5 \%$ and $68.5 \%$. In this respect, La Nef undoubtedly represents an outlier.
} 
Table 7: Yearly Net Benefits of Reciprocity (NBR)

\begin{tabular}{|c|c|c|c|c|c|}
\hline & 2001 & 2002 & 2003 & 2004 & Average \\
\hline$\Delta C D_{t}(€)$ & $59,688.58$ & $90,056.45$ & $141,367.68$ & $186,395.90$ & $119,377.15$ \\
\hline$\Delta I_{t}(€)$ & $15,442.89$ & $28,486.43$ & $56,658.87$ & $65,538.41$ & $41,531.65$ \\
\hline$S C_{t}(€)$ & $53,492.74$ & $88,818.14$ & $131,973.85$ & $132,664.05$ & $101,737.19$ \\
\hline $\begin{array}{c}\boldsymbol{N B R}_{\boldsymbol{t}}(\boldsymbol{(}) \\
=\Delta C D_{t}-\Delta I_{t}-S C_{t}\end{array}$ & - 9,247.06 & - 27,248.12 & - 47,265.04 & - 11,806.55 & - 23,891.69 \\
\hline $\mathrm{NOI}_{t}(€)$ & $51,017.00$ & $208,814.00$ & $235,800.00$ & $199,151.00$ & $173,695.50$ \\
\hline$N B R_{t} / N^{\prime} I_{t}(\%)$ & -18.13 & -13.05 & -20.04 & -5.93 & -14.29 \\
\hline
\end{tabular}

$\Delta C D_{t}$ is the year- $t$ reduction in the cost of default driven by the virtuous repayment conduct of motivated borrowers. $\Delta I_{t}$ is the year- $t$ reduction in cashed-in interests stemming from social premiums offered to motivated borrowers. $S C_{t}$ represents the year- $t$ screening costs associated with assessing the applicants' social ratings. $N B R_{t}$ is the net benefit of reciprocity in year $t$. $\mathrm{NOI}_{t}$ indicates the yearly net operating incomes of $\mathrm{La} \mathrm{Nef}$.

Table 7 summarizes the results. Noticeably, all the estimated values of $N B R_{t}$ are negative, in line with the evidence that investing in social banks entails financial sacrifices (Becchetti and Garcia, 2011; San-Jose et al., 2011). With reference with our theoretical model in Section 2, the figures reveal that the costs associated with social screening $\left(S C_{t}\right)$ are high.

Table 7 also indicates the yearly net operating incomes of $L a N e f, N O I_{t}$ and the values of $N B R_{t}$ scaled by $N O I_{t}$. The figures reveal that the bank's social orientation has a significant cost amounting an average $14.29 \%$ of net operating income. However, this cost is not steady over time.

We run sensitivity analyses with regard to two key parameters. First, we allow the discount rate-set at $6 \%$ in our estimations-to take a wide range of values. Our computations (not reported here) show that $N B R_{t}$ is quite insensitive to a variation in the discount rate. For instance, with discount rates of $2 \%$ and $10 \%$, the average $N B R$ would represent $12.17 \%$ and $16.7 \%$ of the average NOI, respectively. Second, we investigate the impact of the share of overheads attributed to social screening. This share, estimated at $31.84 \%$ in Appendix B, is used to build a proxy for $S C_{t}$. Actually, the analysis reveals that $S C_{t}$-and hence $N B R_{t}-$ is sensitive the share of overheads attributed to social screening. More precisely, reciprocity is 
costly (i.e. the average value of $N B R$ is negative) as soon as the share lies above $24.36 \%$. Determining whether this threshold is realistic remains an open question.

More generally, our model shows that social banks have spillover effects on the whole economy since reciprocity permits the financing of low-risk, efficient projects. However, this positive impact has not been accounted for in the cost-benefit analysis, which is restricted to the bank's perspective.

\section{Robustness Checks}

This section proposes robustness checks on the reciprocity effect detected in Tables 5 and 6 . We run new regressions controlling for two groups of dummy variables neglected so far. ${ }^{30}$ We include each set of variables separately to avoid potential multicollinearity. Additional checks are offered in Appendix C.

The results are summarized in Table 8. In columns (1) to (4), we control for bank branches to reflect the diversity of the French regions. Moreover, the distance between the branches and La Nef's headquarters varies. Distance could indeed matter in communicating soft information to the credit committee (Liberti and Mian, 2009). ${ }^{31}$ In columns (5) to (8), we take into account the borrower's location (town, rural area or suburb). Location is a natural proxy for competition intensity. Banking competition is likely less fierce in remote rural areas or in suburbs than in cities endowed with abundant financial services.

\footnotetext{
${ }^{30}$ The robustness checks are carried out on the reduced sample for which we have full information (367 firms).

${ }^{31}$ Even though La Nef has several branches, it has a single nationwide credit committee. This committee is composed of two persons: a headquarters-based manager and the loan officer. Importantly, branch-based loan officers take active part in the committee's decision making. They can communicate all the relevant soft information either by being on-site or by phone. Since the headquarters are located in the South-East branch, loan officers from that branch perhaps influence the credit conditions more than their colleagues from other branches.
} 
Table 8: Robustness Checks: Additional Dummies

\begin{tabular}{|c|c|c|c|c|c|c|c|c|}
\hline VARIABLES & $\begin{array}{c}(1) \\
\text { OLS } \\
\text { RATE }\end{array}$ & $\begin{array}{c}(2) \\
\text { Probit }^{\mathrm{a}} \\
\text { DEFAULT }\end{array}$ & $\begin{array}{c}(3) \\
\text { OLS } \\
\text { RATE }\end{array}$ & $\begin{array}{c}(4) \\
\text { Probit }^{\mathrm{a}} \\
\text { DEFAULT }\end{array}$ & $\begin{array}{c}(5) \\
\text { OLS } \\
\text { RATE }\end{array}$ & $\begin{array}{c}(6) \\
\text { Probit }^{\mathrm{a}} \\
\text { DEFAULT }\end{array}$ & $\begin{array}{c}(7) \\
\text { OLS } \\
\text { RATE }\end{array}$ & $\begin{array}{c}(8) \\
\text { Probit }^{\mathrm{a}} \\
\text { DEFAULT }\end{array}$ \\
\hline SR & $\begin{array}{c}-0.14 * * * \\
(0.032)\end{array}$ & $\begin{array}{c}-0.09 * * * \\
(0.031)\end{array}$ & $\begin{array}{l}-0.08 * * \\
(0.032)\end{array}$ & $\begin{array}{c}-0.09 * * * \\
(0.032)\end{array}$ & $\begin{array}{c}-0.13 * * * \\
(0.032)\end{array}$ & $\begin{array}{c}-0.09 * * * \\
(0.031)\end{array}$ & $\begin{array}{l}-0.08 * * \\
(0.033)\end{array}$ & $\begin{array}{c}-0.09 * * * \\
(0.032)\end{array}$ \\
\hline FIN & $\begin{array}{c}-0.16 * * * \\
(0.046)\end{array}$ & $\begin{array}{c}-0.13 * * * \\
(0.048)\end{array}$ & $\begin{array}{c}-0.16 * * * \\
(0.045)\end{array}$ & $\begin{array}{l}-0.12 * * \\
(0.049)\end{array}$ & $\begin{array}{c}-0.16 * * * \\
(0.046)\end{array}$ & $\begin{array}{c}-0.13 * * * \\
(0.048)\end{array}$ & $\begin{array}{c}-0.16 * * * \\
(0.045)\end{array}$ & $\begin{array}{l}-0.12 * * \\
(0.049)\end{array}$ \\
\hline PIBOR3M & $\begin{array}{c}0.60 * * * \\
(0.029)\end{array}$ & & $\begin{array}{c}0.49 * * * \\
(0.090)\end{array}$ & & $\begin{array}{c}0.60 * * * \\
(0.029)\end{array}$ & & $\begin{array}{c}0.49 * * * \\
(0.090)\end{array}$ & \\
\hline STARTUP & $\begin{array}{c}0.03 \\
(0.050)\end{array}$ & $\begin{array}{l}0.12 * * \\
(0.049)\end{array}$ & $\begin{array}{c}0.02 \\
(0.048)\end{array}$ & $\begin{array}{l}0.11 * * \\
(0.049)\end{array}$ & $\begin{array}{c}0.02 \\
(0.050)\end{array}$ & $\begin{array}{c}0.13 * * * \\
(0.050)\end{array}$ & $\begin{array}{c}0.02 \\
(0.048)\end{array}$ & $\begin{array}{l}0.11 * * \\
(0.049)\end{array}$ \\
\hline RELATIONSHIP & $\begin{array}{c}0.06 \\
(0.065)\end{array}$ & $\begin{array}{c}-0.09 \\
(0.060)\end{array}$ & $\begin{array}{c}0.02 \\
(0.063)\end{array}$ & $\begin{array}{c}-0.09 \\
(0.058)\end{array}$ & $\begin{array}{c}0.05 \\
(0.065)\end{array}$ & $\begin{array}{c}-0.08 \\
(0.062)\end{array}$ & $\begin{array}{c}0.02 \\
(0.063)\end{array}$ & $\begin{array}{c}-0.09 \\
(0.059)\end{array}$ \\
\hline RATE & & $\begin{array}{l}-0.02 \\
(0.07)\end{array}$ & & $\begin{array}{c}0.03 \\
(0.06)\end{array}$ & & $\begin{array}{l}-0.02 \\
(0.04)\end{array}$ & & $\begin{array}{c}0.03 \\
(0.06)\end{array}$ \\
\hline LOAN SIZE & $\begin{array}{c}-0.02 * * * \\
(0.005)\end{array}$ & $\begin{array}{c}-0.00 \\
(0.005)\end{array}$ & $\begin{array}{c}-0.02 * * * \\
(0.005)\end{array}$ & $\begin{array}{c}0.00 \\
(0.004)\end{array}$ & $\begin{array}{c}-0.02 * * * \\
(0.005)\end{array}$ & $\begin{array}{c}0.00 \\
(0.005)\end{array}$ & $\begin{array}{c}-0.02 * * * \\
(0.005)\end{array}$ & $\begin{array}{c}0.00 \\
(0.004)\end{array}$ \\
\hline NONCOLLAT & $\begin{array}{l}-0.33 * * \\
(0.155)\end{array}$ & $\begin{array}{c}-0.01 \\
(0.173)\end{array}$ & $\begin{array}{l}-0.38 * * \\
(0.153)\end{array}$ & $\begin{array}{c}0.06 \\
(0.183)\end{array}$ & $\begin{array}{l}-0.33 * * \\
(0.157)\end{array}$ & $\begin{array}{c}-0.02 \\
(0.175)\end{array}$ & $\begin{array}{l}-0.38 * * \\
(0.154)\end{array}$ & $\begin{array}{c}0.06 \\
(0.184)\end{array}$ \\
\hline CONSTANT & $\begin{array}{c}5.00 * * * \\
(0.153)\end{array}$ & & $\begin{array}{c}5.14 * * * \\
(0.410)\end{array}$ & & $\begin{array}{c}4.95 * * * \\
(0.154)\end{array}$ & & $\begin{array}{c}5.08 * * * \\
(0.414)\end{array}$ & \\
\hline Year dummies & No & No & Yes & Yes & No & No & Yes & Yes \\
\hline Loan officer dummies & No & No & Yes & Yes & No & No & Yes & Yes \\
\hline Bank branch dummies & Yes & Yes & Yes & Yes & No & No & No & No \\
\hline Borr. loc. dummies & No & No & No & No & Yes & Yes & Yes & Yes \\
\hline Observations & 367 & 367 & 367 & 367 & 367 & 367 & 367 & 367 \\
\hline R-squared & 0.62 & . & 0.67 & . & 0.62 & . & 0.67 & . \\
\hline $\log (\mathrm{L})$ & . & -180.35 & & -171.11 & . & -181.12 & . & -170.95 \\
\hline
\end{tabular}

Overall, Table 8 shows that the previous results resist the inclusion of all the dummies. Moreover, the influence of the refinancing rate (PIBOR3M) is not eliminated by the presence of these variables. This can be seen as confirmation that the bank smoothes interest rates in response to time variations in market rates.

On the whole, the robustness checks confirm our previous findings on the impacts of social rating on both credit conditions and probability of default, respectively. Motivated firms benefit from advantageous interest rates and loan sizes from the social bank, and subsequently reimburse their loans more responsibly than regular firms, all else being equal. 


\section{Conclusion}

Social banks are committed to paying attention to non-financial outcomes of their investments. Their mission differs significantly from that of typical capitalistic banks. That they are able to accomplish this mission is due to the specific orientation of their stakeholders. As savers, cooperative members, or shareholders, social investors accept lower-than-market financial returns provided their money is channeled into social projects. However, this foundational principle imposes no clear-cut investment rules on the managers of social banks. As a consequence, it is worth studying how these institutions grant credit in practice.

Based on a representative European case study, this paper examines how a social bank passes its investors' financial sacrifices through to socially minded borrowers. Our empirical analysis delivers two key messages. First, we show that the sacrifices made by social investors result in rebates on the interest rates charged to borrowers aiming to fund profitable social projects. Well-run motivated firms are eventually able to decrease their cost of capital by borrowing from a social bank. Surprisingly, the growing literature on socially responsible investment is silent on this finding. Second, we document the existence of a reciprocity effect from motivated borrowers. While theoretical and experimental evidence has previously raised that possibility, this paper is the first-to our knowledge-to exhibit a real-life situation involving reciprocity in the banking industry. This innovative result offers promising grounds for further investigation of the features that enhance repayment performances. Relationship lending has long been recognized as a way to overcome moral hazard. But relationships take time to build, and evidently do not apply to start-ups, which are in dire need of funding opportunities. While reciprocity applies only to a specific segment of the banking industry, where investors and borrowers share common values, it may prove to be more efficient in practice. 
Additionally, we show that the social bank is more concerned with increasing the probability of success of viable social projects rather than targeting projects otherwise redlined by commercial banks. Offering cheap credit to such projects likely entails lower financial sacrifices-in terms of both risk and expected returns-than funding below-break-even social projects. This strategy should imply that investing in social banks is safer but less profitable than in mainstream banks. Our results show that, despite the existence of reciprocity, social concern is costly to the bank studied in this paper. Further work could be done to assess the impact of social goals on risk-taking attitudes.

By voluntarily restricting its activity to basic financial intermediation, social banking offers an attractive alternative to the "big bank" model undermined by the recent crisis. Is this a new model applicable to the industry as a whole or is it limited to double-bottom-line institutions? This is debatable. Indeed, social banks currently account for a limited segment of the banking industry, and their action affects the economy only marginally. Moreover, as observed in the microfinance industry, growth is sometimes associated with mission drift (Armendariz and Szafarz, 2011).

It may also be wondered whether the development of social banking would crowd out standard borrowers from the credit market. In a hypothetical world where a significant portion of banks value social performances and total credit is rationed, the share of credit left to nonsocial projects would shrink. However, this scenario is unrealistic in a profit-driven capitalistic economy. Moreover, social and non-social firms naturally belong to different economic sectors. Therefore, social banking hardly distorts competition mechanisms.

The findings of this paper bring important but preliminary insights into the fast-growing industry of social banking. Working with a single institution inevitably restricts the external validity of our conclusions. While $L a N e f$ s operating method is fairly representative of 
European social banks, further work is needed to assess the degree of generalization of our results. Features such as country of origin, legal status, size, age, and governance design might matter.

Admittedly, like most studies concerned with explaining credit terms, our analysis is not immune from selection biases. First, we observe actual loans only and have no information on denied applications. Second, the social nature of the bank could drive a self-selection bias stemming from the applicants' perception of the bank's objectives. Third, in a dynamic perspective, firms with poor social and economic performances are likely washed out. Therefore, the reciprocity effect we detect could be partly attributable to a survival bias. While our theoretical model helps in addressing these arguments, further empirical work is still needed to disentangle the reciprocity effect from the reputation effect associated with relationship lending.

Technically, building a social rating raises specific issues. In the bank under scrutiny in this paper, the social rating is meant to measure idiosyncratic characteristics, such as the borrower's moral rectitude and social motivation, the ethicality of the core business, the corporate responsibility to stakeholders, environmental and social concerns, etc. The computation of this social rating does not abide by strict rules, and is therefore difficult to assess through a standardized procedure. It relies heavily on soft information, mainly collected by loan officers whose objectivity may be questioned (Agier and Szafarz, 2013b). ${ }^{32}$ This new type of agency problem may compromise the fulfillment of the bank's social mission.

On the whole, this paper contributes to the understanding of the way social banks operate in the credit market, a topic largely overlooked in the literature so far. In particular, it

\footnotetext{
${ }^{32}$ In other social banks, the social assessment is carried out according to distinct procedures. For example, in Banca Etica (Italy), a thorough social audit is conducted by the so-called "social auditors or experts", who are cooperative members trained by the bank.
} 
shows that the loans granted by social banks share characteristics both with commercial loans from mainstream banks and with subsidized credit from public institutions. This new and promising model of banking activity undoubtedly calls for further investigation. 


\section{References}

Adbulkardiroglu, A. and K. Bagwell (2013), “Trust, Reciprocity, and Favors in Cooperative Relationships," American Economic Journal: Microeconomics 5, 213-259.

Agier, I. and A. Szafarz (2013a), "Microfinance and Gender: Is There a Glass Ceiling on Loan Size?" World Development 42, 165-181.

Agier, I. and A. Szafarz (2013b), "Subjectivity in Credit Allocation to Micro-Entrepreneurs: Evidence from Brazil," Small Business Economics 41, 263-275.

Ahmed, A.S., C. Takeda and S. Thomas (1999), "Bank Loan Loss Provisions: A Reexamination of Capital Management, Earnings Management and Signaling Effects," Journal of Accounting and Economics 28, 1-25.

Akerlof, G.A. and R.E. Kranton (2000), "Economics and Identity," Quarterly Journal of Economics 115, 715-733.

Akerlof, G.A. and R.E. Kranton (2005), "Identity and the Economics of Organizations," Journal of Economic Perspective 19, 9-32.

Allet, M. and M. Hudon (2013), "Green Microfinance. Characteristics of Microfinance Institutions Involved in Environmental Management," CEB Working Paper No 13/005, Université Libre de Bruxelles.

Armendariz, B. and J. Morduch (2010), The Economics of Microfinance, Second Edition, Cambridge, MA: MIT Press.

Armendariz, B. and A. Szafarz (2011), "On Mission Drift in Microfinance Institutions," in: Armendariz, B. and M. Labie (Eds), The Handbook of Microfinance, London Singapore: World Scientific Publishing, 341-366.

Banque Populaire de l'Ouest (2010), Annual Report.

Barigozzi, F. and P. Tedeschi (2011), “Credit Markets with Ethical Banks and Motivated Borrowers," Working Paper DSE No 786, University of Bologna.

Basel Committee on Banking Supervision (2001), The New Basel Capital Accord. Consultative Document.

Becchetti, L. and M. Garcia (2011), "Do Collateral Theories Work in Social Banking?" Applied Financial Economics 21, 931-947.

Becchetti, L., M. Garcia and G. Trovato (2011), "Credit Rationing and Credit View: Empirical Evidence from Loan Data," Journal of Money, Credit and Banking 43, 1217 1245. 
Becchetti, L. and B. Huybrechts (2008), "The Dynamics of Fair Trade as a Mixed-Form Market," Journal of Business Ethics 81, 733-750.

Benabou, R. and J. Tirole (2010), "Individual and Corporate Social Responsibility," Economica 77, 1-19.

Benedikter, R. (2011), Social Banking and Social Finance, New York: Springer.

Berger, A.N. and G.F. Udell (1995), "Relationship Lending and Lines of Credit in Small Firm Finance," Journal of Business 68, 351-381.

Berger, A.N., R.J. Rosen and G.F. Udell (2007), "Does Market Size Structure Affect Competition: The Case of Small Business Lending," Journal of Banking \& Finance 31, 11-33.

Boot, A.W.A. (2000), "Relationship Banking: What Do We Know?" Journal of Financial Intermediation 9, 7-25.

Brown, M., E. Fehr and C. Zehnder (2009), "Reputation: A Microfoundation of Contract Enforcement and Price Rigidity," Economic Journal 111, 333-353.

Brown, M. and C. Zehnder (2007), "Credit Reporting, Relationship Banking and Loan Repayment," Journal of Money, Credit and Banking 39, 1883-1918.

Chakraborty, A. and C. Hu (2006), "Lending Relationships in Line-of-Credit and Non-Lineof-Credit Loans: Evidence from Collateral Use in Small Business," Journal of Financial Intermediation 15, 86-107.

Chen, Y. and S.X. Li (2009), "Group Identity and Social Preferences," American Economic Review 99, 431-457.

Cornée, S., D. Masclet, and G. Thenet (2012), "Credit Relationships: Evidence from Experiments with Real Bankers," Journal of Money, Credit and Banking 44, 957-980.

Cowan, C.D. and A.M. Cowan (2006), “A Survey Based Assessment of Financial Institution Use of Credit Scoring for Small Business Lending," Office of Advocacy, US Small Business Administration.

Cowton, C.J. (2002), "Integrity, Responsibility and Affinity: Three Aspects of Ethics in Banking," Business Ethics: A European Review 11, 393-400.

Cowton, C. and P. Thomspon (2000), "Do Codes Make a Difference? The Case of Bank Lending and the Environment," Journal of Business Ethics 24, 165-178.

Crédit Agricole Ille-et-Vilaine (2010), Annual Report.

Crédit Mutuel Arkéa (2011), Annual Report. 
Defourny, J. (2001), "From Third Sector to Social Enterprise," in: Borzaga, C. and J. Defourny (Eds), The Emergence of Social Enterprise, London - New York: Routledge, 118.

Degryse, H. and P. Cayseele (2000), "Relationship Lending within a Bank-Based System: Evidence from European Small Business Data," Journal of Financial Intermediation 9, 90-109.

Dufwenberg, M. and G. Kirchsteiger (2004), “A Theory of Sequential Reciprocity," Games and Economic Behavior 47, 268-298.

Elsas, R. and J.P. Krahnen (1998), "Is Relationship Lending Special? Evidence from CreditFile Data in Germany?” Journal of Banking \& Finance 22, 1283-1316.

Fehr, E. and U. Fischbacher (2002), "Why Social Preferences Matter - The Impact of NonSelfish Motives on Competition, Cooperation and Incentives," Economic Journal 112, 133.

Fehr, E., S. Gächter, and G. Kirchsteiger (1997), "Reciprocity as a Contract Enforcement Device: Experimental Evidence," Econometrica 65, 833-860.

Fehr, E. and K. Schmidt (1999), "A Theory of Fairness, Competition and Cooperation," Quarterly Journal of Economics 114, 817-868.

Fehr, E. and K. Schmidt (2003), "Theories of Fairness and Reciprocity - Evidence and Economic Applications," in M. Dewatripont, L. Hansen, and S. Turnovsky (Eds.), Advances in Economics and Econometrics - $8^{\text {th }}$ World Congress, Econometric Society Monographs, Cambridge: Cambridge University Press.

Fehr, E. and C. Zehnder (2006), "Reputation and Credit Market Formation," FINRISK Working Paper, University of Zurich.

Ferri, G., P. Kalmi and E. Kerola (2010), “Organizational Structure and Performance in European Banks: A Reassessment," Paper prepared for the EURICSE Conference "Financial Co-operative Approaches to Local Development through Sustainable Innovation".

GABV (Global Alliance for Banking on Value) (2012), Full Report, http://www.gabv.org/wpcontent/uploads/Full-Report-GABV-v9d.pdf.

Gächter, S. and Falk, A. (2002), "Reputation and Reciprocity: Consequences for the Labour Relation," Scandinavian Journal of Economics 104, 1-27.

Global Report Initiative (2011), Sustainability Reporting Guidelines, version 3.1. WwW.globalreporting.org. 
Gouteroux, C. (2006) "Le système bancaire et financier français en 2005," Bulletin de la Banque de France 151, 75-85.

Green, C.F. (1989), “Business Ethics in Banking,” Journal of Business Ethics 8, 631-634.

Grunert, J., L. Norden and M. Weber (2005), "The Role of Non-Financial Factors in Internal Credit Ratings," Journal of Banking \& Finance 29, 509-531.

Gutiérrez-Nieto, B., C. Serrano-Cinca, and J. Camón-Cala (2011), “A Credit Score System for Socially Responsible Lending," CEB Working Paper No 11/028, Université Libre de Bruxelles.

Hudon, M. (2007), "Fair Interest Rates when Lending to the Poor," Ethics and Economics 5, $1-8$.

Iannotta, G., G. Nocera, and A. Sironi (2007), “Ownership Structure, Risk and Performance in the European Banking Industry," Journal of Banking \& Finance 31, 2127-2149.

Jaffee, D. M. and T. Russell (1976), "Imperfect Information, Uncertainty, and Credit Rationing," Quarterly Journal of Economics 90, 651-66.

Karlan D. (2005), "Using Experimental Economics to Measure Social Capital and Predict Financial Decisions," American Economic Review 95, 1688-1699.

Kitson, A. (1996), "Taking the Pulse: Ethics and the British Cooperative Bank," Journal of Business Ethics 15, 1021-1031.

La Nef (2001, 2002, 2003, 2004, 2006, 2010), Annual Reports.

Liberti, J. and A. Mian (2009), "Estimating the Effect of Hierarchies on Information Use," Review of Financial Studies 22, 4057-4090.

Machauer, A. and M. Weber (1998), "Bank Behavior Based on Internal Credit Ratings of Borrowers," Journal of Banking \& Finance 22, 1355-1383.

McLeish, K.J. and R.J. Oxoby (2011), "Social Interactions and the Salience of Social Identity," Journal of Economic Psychology 32, 172-178.

Ory, Jean-Noël, M. Jaeger and E. Gurtner (2006) "La banque à forme coopérative peut-elle soutenir durablement la compétition avec la banque SA ?" Finance Contrôle Stratégie 9, 121-157.

Norman, W. and C. MacDonald (2004) "Getting to the Bottom of 'Triple Bottom Line,", Business Ethics Quarterly 14, 243-262.

Petersen, M. and R. Rajan (1994), “The Benefits of Lending Relationships: Evidence from Small Business Data," Journal of Finance 49, 3-37. 
Périlleux, A., M. Hudon, and E. Bloy (2012), "Surplus distribution in Microfinance: Differences among Cooperatives, Nonprofit, and Shareholder Forms of Ownership," Nonprofit and Voluntary Sector Quarterly 41, 386-404.

Rabin, M. (1993), "Incorporating Fairness into Game Theory and Economics," American Economic Review 83, 1281-1302.

Robert de Massy, O. and G. Lhomme (2008), "Les nouvelles frontières de la formation bancaire," Revue d'Economie Financière 92, 229-243.

San-Jose, L., J.L. Retolaza, and J. Gutierrez (2011), "Are Ethical Banks Different? A Comparative Analysis Using the Radical Affinity Index," Journal of Business Ethics 100, 151-173.

Scholtens, B. (2006), "Finance as a Driver of Corporate Social Responsibility," Journal of Business Ethics 68, 19-31.

Stiglitz, J. and A. Weiss (1981), "Credit Rationing in Markets with Imperfect Information," American Economic Review 71, 393-410.

Taupin, M.T. and P. Glémain (2007), "Les logiques d'acteurs des finances solidaires contemporaines : Entre innovation et résilience," Annals of Public and Cooperative Economics 78, 629-661.

Uzzi, B. (1999), "Embeddedness in the Making of Financial Capital: How Social Relations and Networks Benefit Firms Seeking Financing," American Sociological Review 64, 481-505.

Weber, O. and S. Remer (2011), Social Banks and the Future of Sustainable Finance, London - New York: Routledge. 
APPENDIX A: La Nef's Organizational Characteristics

Table A1: Geographic Breakdown of the Loans Granted by La Nef (2001-2004)

\begin{tabular}{|c|c|c|}
\hline $\begin{array}{c}\text { Bank } \\
\text { Branch }\end{array}$ & Metropolitan regions & Loans \\
\hline \multirow{9}{*}{$\begin{array}{c}\text { SOUTH } \\
\text { EAST }\end{array}$} & $\begin{array}{c}\text { Provence-Alpes-Côte } \\
\text { d'Azur }\end{array}$ & 53 \\
\hline & Rhône-Alpes & 38 \\
\hline & Bourgogne & 6 \\
\hline & Alsace & 0 \\
\hline & Corse & 0 \\
\hline & Franche-Comté & 5 \\
\hline & Auvergne & 8 \\
\hline & Languedoc & 9 \\
\hline & Total & 119 \\
\hline \multirow{11}{*}{$\begin{array}{c}\text { PARIS, } \\
\text { NORTH } \\
\text { WEST }\end{array}$} & Basse-Normandie & 43 \\
\hline & Bretagne & 28 \\
\hline & Centre & 7 \\
\hline & Champagne & 2 \\
\hline & Haute-Normandie & 7 \\
\hline & Ile-de-France & 86 \\
\hline & Lorraine & 5 \\
\hline & Nord & 2 \\
\hline & Pays-de-la-Loire & 15 \\
\hline & Picardie & 3 \\
\hline & Total & 198 \\
\hline \multirow{5}{*}{$\begin{array}{c}\text { SOUTH } \\
\text { WEST }\end{array}$} & Aquitaine & 6 \\
\hline & Midi-Pyrénées & 27 \\
\hline & Limousin & 7 \\
\hline & Poitou-Charente & 10 \\
\hline & Total & 50 \\
\hline \multicolumn{2}{|r|}{ Grand total } & 367 \\
\hline
\end{tabular}

Notes: Over the study period, the regional remit of some branches has changed. When this is the case, we have favored the branch in charge of the region for the longest period. Due to data unavailability, the figures are computed on a sub-sample of 367 borrowers. 


\section{Appendix B: Technicalities in the Cost-Benefit Analysis of Reciprocity}

Here we report the detailed computation of three components of $N B R$ in Eq. (3).

\section{1) Computation of $\Delta C D_{t}$}

La Nef is committed to report loan-disaggregated LLPs to the French banking authority on a quarterly basis. We managed to gain access to the report released in the first quarter of 2007 (this also gives the level of provisioning for the last quarter of 2006), while our sample period ends in November 2008. As a result, we have detailed information on LLPs for 65 loans out of the 91 defaulted loans in our sample (i.e. $71.4 \%$ ). We have estimated the missing LLPs by multiplying the respective loan sizes by the average provisioning rate computed from the observable LLPs. This average rate is $27.54 \% .{ }^{33}$ One could object that LLPs are adjusted over time in reaction to changes in default expectations. In practice, however, the adjustments prove to be limited. Between the last quarter of 2006 and the first quarter of 2007, the average LLP adjustment was $2.58 \%$ only. Therefore, we consider that the missing one-year adjustment does not affect $\triangle D C$ much. Last, we discounted all the LLPs according to the year of default.

To measure how reciprocity reduces the cost of default, we run a Tobit regression (see Table B1). The explained variable is the present value of LLPs for defaulted loans, and 0 otherwise. The explanatory variable of interest is SR. We also include control variables accounting for contractual features, financial risk characteristics, and relational aspects. The marginal effects reported in Column (2) indicate that the present value of LLP decreases by $€ 1,047.72$ per unit of SR. In this way, we obtain the differential LLPs driven by each actual loan with SR $=2$ or 3 . Summing up, we obtain an estimate of the total benefit attributable to the reduction in yearly default occurrences.

\footnotetext{
${ }^{33}$ The provisioning rate of a loan in default is equal to LLP / loan size.
} 
Table B1: Tobit Regression for LLP (discount rate $=6 \%$ )

\begin{tabular}{lcc}
\hline & $(1)$ & $(2)$ \\
VARIABLES & LLP & Marg. Effects \\
\hline \multirow{2}{*}{ SR } & & \\
& $-4,855.54 * *$ & $-1,047.17 * *$ \\
FIN & $(2,033.055)$ & $(432.960)$ \\
& $-8,717.91 * * *$ & $-1,880.14^{* * *}$ \\
STARTUP & $(3,216.189)$ & $(680.200)$ \\
& $8,953.55^{* * *}$ & $1,928.87 * * *$ \\
RELATIONSHIP & $(3,225.034)$ & $(696.110)$ \\
& $-4,881.30$ & $-1,004.81$ \\
RATE & $(4,806.737)$ & $(939.300)$ \\
& 597.75 & 128.91 \\
LOANSIZE & $(3,475.278)$ & $(749.520)$ \\
& $0.08 * *$ & $0.01 * *$ \\
NONCOLLAT & $(0.035)$ & $(0.007)$ \\
& $7,589.73$ & $1,636.83$ \\
CONSTANT & $(9,958.397)$ & $(2,147.300)$ \\
& $-5,041.89$ & \\
Year dummies & $(26,374.540)$ & \\
\hline Observations & Yes & Yes \\
Log (L) & 389 & 389 \\
\hline
\end{tabular}

\section{2) Computation of $\Delta I_{t}$}

We compute the differential in cashed-in interests as follows. For each loan in our sample, we compare two situations: The actual one and its " $\mathrm{SR}=1$ " simulated counterpart. The aim is to compute the discounted cashed-in interests for the two situations, and then take the difference between them. To simplify the computations, we work out annual installment (constant annuities) even though borrowers repay in monthly installments.

Table B2 depicts an example. The 5-year loan amounts $€ 50,000$. The actual interest charged by the bank on this loan is $5 \%$ and the actual social rating is 3 . From Table 5 (Specification (3)), we find that the simulated counterpart of the loan bears interest at $5.30 \%$. Table 5 extracts the annual interest paid on both loans (5\% and 5.30\%). Annual differences are then computed and discounted at a $6 \%$ rate. The final result is the sum of these figures, i.e. $€ 418.05$. Similar calculations are conducted for all the loans in our sample. 
Table B2: Difference in Cashed-in Interests: An Example (loan size $=€$ 50,000; $\mathbf{S R}=3$ )

\begin{tabular}{|c|c|c|c|c|c|c|}
\hline & \multicolumn{5}{|c|}{ Year } & \\
\hline & 1 & 2 & 3 & 4 & 5 & \\
\hline $\begin{array}{c}\text { Actual interests paid } \\
(\mathrm{r}=5 \%)\end{array}$ & $2,500.00$ & $2,047.56$ & $1,572.50$ & $1,073.69$ & 549.94 & \\
\hline $\begin{array}{c}\text { Simulated interests } \\
\text { if } \mathrm{SR}=\mathbf{1} \\
(\mathbf{r}=\mathbf{5 . 3 0 \%})\end{array}$ & $2,650.00$ & $2,173.28$ & $1,671.30$ & $1,142.71$ & 586.10 & \\
\hline $\begin{array}{c}\text { Difference in cashed-in } \\
\text { interests }\end{array}$ & 150.00 & 125.72 & 98.80 & 69.02 & 36.16 & Total \\
\hline $\begin{array}{l}\text { Discounted difference in } \\
\text { cashed-in interests }\end{array}$ & 141.51 & 111.89 & 82.95 & 54.67 & 27.02 & 418.05 \\
\hline
\end{tabular}

\section{3) Computation of $S C_{t}$}

Loan officers represent the main cost drivers of screening costs. To evaluate the proportion of the extra cost dedicated to social screening, we gauge the productivity of La Nef's loan officers compared with that of loan officers in non-social banks dealing with the same type of borrowers (i.e. small-and-medium-sized enterprises, henceforth SMEs). The productivity of a loan officer is proxied by the number of loans she grants annually. Informal contacts with $L a$ Nef's managers have revealed that, according to their standard, a full-time loan officer grants 25 loans annually. In comparable non-social banks, we have estimated this load to be $36.67 .^{34}$ We therefore attribute $31.84 \%$ of the workload of loan officers in La Nef to social screening.

We use the conservative assumption that the screening operation overheads (SCO) are fully captured by the operational costs associated with loan officers, including wages. To determine those costs, we proceed as follows (see Table B3). First, we extract from La Nef's

\footnotetext{
${ }^{34}$ To obtain this figure, we have combined two sources of information. First, Robert de Massy and Lhomme (2008), mention that on average $15.97 \%$ of total staff in French banks are devoted to the screening of SME loan applicants. Second, from annual reports (2010 annual report of Banque Populaire de l'Ouest, 2010 annual report of Crédit Agricole Ille-et-Vilaine, and 2011 annual report of Crédit Mutuel Arkéa) of regional branches of the three major French cooperative banks dealing with SMEs we estimate their numbers of SME loans per officer: 41.09, 35.25 and 33.68 for Banque Populaire de l'Ouest, Crédit Agricole Ille-et-Vilaine, and Crédit Mutuel Arkéa, respectively. Averaging these figures yields 36.67 loans granted per officer per year. This computation is somewhat heroic since the activity sector, the type of clientele, and the lending technology should be held constant.
} 
annual reports the yearly overhead expenses incurred by all the bank's operations, the yearly full staff sizes, and the yearly numbers of active loan officers (La Nef, 2001, 2002, 2003, and 2004). Second, we compute the year- $t$ average cost per staff member by dividing the overhead expenses in year $t$ by the number of full-time staff members active during year $t$. Third, we derive the year- $t$ SCO by multiplying the number of full-time loan officers active in year $t$ by the year- $t$ average cost per staff member. The SCOs include both financial and social screening costs but exclude those associated with back-office personnel. Last, to estimate $S C_{t}$, we multiply the year- $t$ SCO by the $31.84 \%$ factor representing the excess workload of loan officers due to social screening.

Table B3: Computation of $S C_{t}$

\begin{tabular}{|c|c|c|c|c|}
\hline Year & $\mathbf{2 0 0 1}$ & $\mathbf{2 0 0 2}$ & $\mathbf{2 0 0 3}$ & $\mathbf{2 0 0 4}$ \\
\hline Average cost per staff member & $68,041.96$ & $75,066.67$ & $79,937.50$ & $81,128.21$ \\
\hline Full-time loan officers & 2.47 & 3.72 & 5.19 & 5.14 \\
\hline Screening operation overheads (SCO) & $168,004.83$ & $278,951.44$ & $414,490.74$ & $416,658.44$ \\
\hline$S C=\mathbf{3 1 . 8 4 \%} *$ SCO & $53,492.74$ & $88,181.14$ & $131,973.85$ & $132,664.05$ \\
\hline
\end{tabular}




\section{Appendix C: Additional Robustness Checks}

We carry out four additional robustness checks on the full sample. First, Table $\mathrm{C} 1$ gives the results from the multivariate estimation of specification (2) in Table 5. It is based on reducedform estimation. In this way, we assess the impacts of loan characteristics on credit conditions, while avoiding potential endogeneity biases.

\section{Table C1: Robustness Check: Multivariate Regression for the Credit Conditions}

\begin{tabular}{lccc}
\hline \multirow{2}{*}{ VARIABLES } & $(1)$ & $(2)$ & $(3)$ \\
SR & RATE & LOANSIZE & NONCOLLAT \\
& $-0.15^{* * *}$ & $0.90 * * *$ & 0.01 \\
FIN & $(0.032)$ & $(0.325)$ & $(0.011)$ \\
& $-0.15 * * *$ & -0.03 & -0.02 \\
PIBOR3M & $(0.048)$ & $(0.483)$ & $(0.017)$ \\
& $0.61 * * *$ & $-0.83 * * *$ & $-0.04 * * *$ \\
STARTUP & $(0.029)$ & $(0.295)$ & $(0.010)$ \\
& 0.03 & $-2.13 * * *$ & $0.03 *$ \\
RELATIONSHIP & $(0.050)$ & $(0.500)$ & $(0.017)$ \\
& -0.02 & -0.72 & $0.04 *$ \\
CONSTANT & $(0.066)$ & $(0.661)$ & $(0.023)$ \\
& $4.84 * * *$ & $6.17 * * *$ & $0.25 * * *$ \\
Observations & $(0.148)$ & $(1.489)$ & $(0.051)$ \\
R-squared & 389 & 389 & 389 \\
*: significant at the $10 \%$ level, **: significant at the $5 \%$ level, ***: significant at the $1 \%$ level.
\end{tabular}

Overall, the figures in the first column of Table $\mathrm{C} 1$ confirm those in Table 5 regarding the impact of the social rating on interest rates. R-squares indicate that the adjustment is poor for the other credit conditions. This can be attributed to two factors. First, loan size alone is a loose indicator of credit rationing. Its determination is most likely influenced by the requested amount, which is unobservable. Second, collateralization for start-ups is highly dependent on public guarantees, which are also unobservable. Both limitations might create missingvariable distortions in the estimations of loan size and collateralization. Nevertheless, reduced-form estimation has the merit of freeing the interest rate loadings from these distortions. 
Table C2: Robustness Check: Alternative Specifications for Social Rating

\begin{tabular}{|c|c|c|c|c|c|}
\hline & (1) & (2) & (3) & (4) & (5) \\
\hline VARIABLES & $\begin{array}{c}\text { Ordered } \\
\text { Probit }^{\mathrm{a}} \\
\text { SR }\end{array}$ & $\begin{array}{c}\text { OLS } \\
\text { RATE }\end{array}$ & $\begin{array}{c}\text { Probit }^{\mathrm{a}} \\
\text { DEFAULT }\end{array}$ & $\begin{array}{c}\text { OLS } \\
\text { RATE }\end{array}$ & $\begin{array}{c}\text { Probit }^{\mathrm{a}} \\
\text { DEFAULT }\end{array}$ \\
\hline PSR & & $\begin{array}{c}-0.13 * * * \\
(0.032)\end{array}$ & $\begin{array}{c}-0.09 * * * \\
(0.029)\end{array}$ & & \\
\hline DICSR & & & & $\begin{array}{l}-0.15^{* *} \\
(0.059)\end{array}$ & $\begin{array}{l}-0.14 * * \\
(0.061)\end{array}$ \\
\hline FIN & $\begin{array}{c}0.10 \\
(0.122)\end{array}$ & $\begin{array}{c}-0.16 * * * \\
(0.047)\end{array}$ & $\begin{array}{c}-0.13 * * * \\
(0.046)\end{array}$ & $\begin{array}{c}0.16^{* * *} \\
(0.047)\end{array}$ & $\begin{array}{c}-0.12 * * * \\
(0.047)\end{array}$ \\
\hline PIBOR3M & & $\begin{array}{c}0.59 * * * \\
(0.030)\end{array}$ & & $\begin{array}{c}0.59 * * * \\
(0.030)\end{array}$ & \\
\hline STARTUP & $\begin{array}{c}-0.45^{* * * *} \\
(0.123)\end{array}$ & $\begin{array}{c}0.03 \\
(0.050)\end{array}$ & $\begin{array}{c}0.16^{* * *} \\
(0.046)\end{array}$ & $\begin{array}{c}0.01 \\
(0.051)\end{array}$ & $\begin{array}{c}0.14 \\
(0.047)\end{array}$ \\
\hline RELATIONSHIP & $\begin{array}{c}0.19 \\
(0.167)\end{array}$ & $\begin{array}{c}-0.04 \\
(0.065)\end{array}$ & $\begin{array}{l}-0.10^{*} \\
(0.05)\end{array}$ & $\begin{array}{c}-0.03 \\
(0.066)\end{array}$ & $\begin{array}{c}-0.10 \\
(0.057)\end{array}$ \\
\hline RATE & & & $\begin{array}{c}-0.02 \\
(0.034)\end{array}$ & & $\begin{array}{c}-0.01 \\
(0.034)\end{array}$ \\
\hline LOANSIZE & & $\begin{array}{c}-0.02 * * * \\
(0.005)\end{array}$ & $\begin{array}{c}0.00 \\
(0.005)\end{array}$ & $\begin{array}{l}0.02 * * \\
(0.005)\end{array}$ & $\begin{array}{c}0.00 \\
(0.005)\end{array}$ \\
\hline NONCOLLAT & & $\begin{array}{c}-0.15 \\
(0.146)\end{array}$ & $\begin{array}{c}-0.01 \\
(0.154)\end{array}$ & $\begin{array}{c}-0.17 \\
(0.147)\end{array}$ & $\begin{array}{c}-0.01 \\
(0.153)\end{array}$ \\
\hline CONSTANT & & $\begin{array}{l}4.70 * * * \\
(0.136)\end{array}$ & & $\begin{array}{c}4.81 * * * \\
(0.145)\end{array}$ & \\
\hline Cut 1 & $\begin{array}{c}-0.89 * * * \\
(0.257)\end{array}$ & & & & \\
\hline Cut 2 & $\begin{array}{c}0.38 \\
(0.254) \\
\end{array}$ & & & & \\
\hline Observations & 389 & 389 & 389 & 389 & 389 \\
\hline $\begin{array}{l}\text { R-squared } \\
\text { Log (L) }\end{array}$ & $\begin{array}{c}\cdot \\
-394.74 \\
\end{array}$ & $\begin{array}{c}0.57 \\
. \\
\end{array}$ & $\begin{array}{c}\cdot \\
-194.14 \\
\end{array}$ & $\begin{array}{c}0.57 \\
. \\
\end{array}$ & $\begin{array}{c}\cdot \\
-193.29 \\
\end{array}$ \\
\hline
\end{tabular}

Second, in Table C2 we propose two alternative specifications for the measurement of the social rating. First, we use two-step estimations to clean the social rating of its interactions with other loan characteristics. In column (1), an ordered probit regression model extracts the residuals of SR when regressed on FIN, STARTUP, and RELATIONSHIP. These residuals constitute "pure" social ratings (PSR). Only the start-up dummy is significant in the first-path regression. Then, the interest rate (column (2)) is estimated by substituting PSR for SR. The 
empirical results prove to be robust to this change. The negative impact of PSR on the probability of default (column (3)) is the same as that of SR in Table 6. We thus exclude any spurious effect due to accidental correlations between the social rating and other loan characteristics. Second, in columns (4) and (5), we dichotomize the social rating and use variable DICSR, which takes value 0 if $\mathrm{SR}=1$, and 1 when $\mathrm{SR}>1$. The aim is to limit the impact of the ordinality of the SR rating. According the La Nef's criterion, DICSR = 1 indicates that the projects have at least one social or environmental component. Except for the significance level, which passes from $1 \%$ to $5 \%$, dichotomizing the social rating does not modify the previous results. The negative impact of DICSR on the probability of default (column (5)) is even stronger than that of SR in Table 6. Altogether, Table C2 not only confirms our previous results, they also emphasize that our findings are driven by purely social motives.

Third, we run instrumental-variable estimation to account for the possibility of SR being endogenous. The results (not reported here) show that the Durbin-Wu-Hausman test fails to reject the null hypothesis that SR is exogenous $(p=0.6584){ }^{35}$

Fourth, Table C3 proposes two specifications including additional explanatory variables. Columns (1) and (2) in Table C3 examine whether the impact of the social ratings is partly attributable to loan size. The descriptive statistics in Section 3 pointed out that borrowers with higher social ratings tend to receive larger loans. In fact, we checked the potential effect of loan size in two ways. First, we estimated the two equations (for rate and default) on a censored sample obtained by excluding the largest loans. Several cut-off points

\footnotetext{
${ }^{35}$ We used the following instrumental variables: ENVIRONMENT (dummy variable taking value 1 if the borrowing firm works in the environmental sector, and zero otherwise), RURAL (dummy variable taking value 1 if the borrowing firm is located in a rural area, and zero otherwise), NONPROF (dummy variable taking value 1 if the borrowing firm is a not-for-profit organization, and zero otherwise), UNLIMITED (dummy variable taking value 1 if the borrowing firm is an unlimited company, and zero otherwise), CONSORTIUM (dummy variable taking value 1 if the borrowing firm belongs to a consortium, and zero otherwise), and the duplicates (STARTUP and RELATIONSHIP).
} 
were used (results not reported). All of them produced results consistent with those from our baseline regressions. Second, we added the interaction between loan size and social rating among the explanatory variables. Table $\mathrm{C} 3$ reveals that the loadings of this interaction term in our two regressions of interest are insignificant. Loan size does not interfere with the reciprocity effect.

Table C3: Robustness Check: Additional Explanatory Variables

\begin{tabular}{|c|c|c|c|c|}
\hline VARIABLES & $\begin{array}{c}(1) \\
\text { OLS } \\
\text { RATE }\end{array}$ & $\begin{array}{c}(2) \\
\text { Probit }^{\mathrm{a}} \\
\text { DEFAULT }\end{array}$ & $\begin{array}{c}(3) \\
\text { OLS } \\
\text { RATE }\end{array}$ & $\begin{array}{c}(4) \\
\text { Probit }^{\mathrm{a}} \\
\text { DEFAULT }\end{array}$ \\
\hline SR & $\begin{array}{c}-0.16 * * * \\
(0.045)\end{array}$ & $\begin{array}{c}-0.08 * * \\
(0.043)\end{array}$ & $\begin{array}{c}-0.13 * * * \\
(0.031)\end{array}$ & $\begin{array}{c}-0.08 * * \\
(0.030)\end{array}$ \\
\hline FIN & $\begin{array}{c}-0.16^{* * *} \\
(0.047)\end{array}$ & $\begin{array}{c}-0.12 * * * \\
(0.046)\end{array}$ & $\begin{array}{c}-0.16 * * * \\
(0.047)\end{array}$ & $\begin{array}{c}-0.12 * * * \\
(0.048)\end{array}$ \\
\hline PIBOR3M & $\begin{array}{c}0.59 * * * \\
(0.030)\end{array}$ & & $\begin{array}{c}0.59 * * * \\
(0.028)\end{array}$ & \\
\hline STARTUP & $\begin{array}{c}-0.01 \\
(0.050)\end{array}$ & $\begin{array}{c}0.13 * * * \\
(0.047)\end{array}$ & $\begin{array}{c}0.06 \\
(0.055)\end{array}$ & $\begin{array}{c}0.02 \\
(0.055)\end{array}$ \\
\hline RELATIONSHIP & $\begin{array}{c}-0.02 \\
(0.065)\end{array}$ & $\begin{array}{c}-0.10 \\
(0.056)\end{array}$ & $\begin{array}{c}0.03 \\
(0.064)\end{array}$ & $\begin{array}{c}-0.07 \\
(0.061)\end{array}$ \\
\hline RATE & & $\begin{array}{c}-0.02 \\
(0.034)\end{array}$ & & $\begin{array}{c}-0.00 \\
(0.036)\end{array}$ \\
\hline LOANSIZE & $\begin{array}{l}-0.04 * \\
(0.019)\end{array}$ & $\begin{array}{c}0.00 \\
(0.017)\end{array}$ & $\begin{array}{l}-0.02 * \\
(0.018)\end{array}$ & $\begin{array}{c}0.00 \\
(0.005)\end{array}$ \\
\hline NONCOLLAT & $\begin{array}{c}-0.14 \\
(0.147)\end{array}$ & $\begin{array}{l}-0.015 \\
(0.155)\end{array}$ & $\begin{array}{c}-0.34 \\
(0.154)\end{array}$ & $\begin{array}{c}-0.06 \\
(0.155)\end{array}$ \\
\hline SR*LOANSIZE & $\begin{array}{c}0.01 \\
(0.008)\end{array}$ & $\begin{array}{c}-0.00 \\
(0.007)\end{array}$ & & \\
\hline PUBLIC COLLAT & & & $\begin{array}{c}-0.08 \\
(0.05)\end{array}$ & $\begin{array}{c}0.21 * * * \\
(0.055)\end{array}$ \\
\hline CONSTANT & $\begin{array}{c}5.06 * * * \\
(0.174) \\
\end{array}$ & & $\begin{array}{c}5.06 * * * \\
(0.174)\end{array}$ & \\
\hline Observations & 389 & 389 & 367 & 367 \\
\hline R-squared & 0.59 & . & 0.61 & . \\
\hline $\log (\mathrm{L})$ & . & -191.09 & . & -173.14 \\
\hline
\end{tabular}

As explained in Section 3, some loans, especially those made to start-ups, benefit from public collateral. The subsequent incentive may affect the bank's lending behavior. We investigate this possibility in columns (3) and (4) in Table C3 by including the dummy 
variable PUBLIC COLLAT (equal to 1 if the loan benefits from public collateral, and 0 otherwise). The regression results show that public collateral has a significantly negative impact on the probability of default. Meanwhile, the STARTUP dummy loses significance, which might indicate the presence of multicollinearity between STARTUP and PUBLIC COLLAT. In any case, the impacts of our variables of interest, SR and FIN, remain consistent with those obtained from our baseline regressions. 